\title{
Natural capital for nature's contributions to people: the case of Japan
}

\author{
Junya Kumagai ${ }^{1}$ (1) $\cdot$ Mihoko Wakamatsu $^{2} \cdot$ Shizuka Hashimoto $^{3} \cdot$ Osamu Saito $^{4} \cdot$ Takehito Yoshida $^{5}$. \\ Takehisa Yamakita $^{6} \cdot$ Keiko Hori $^{7} \cdot$ Takanori Matsui $^{8} \cdot$ Michio Oguro $^{9} \cdot$ Masahiro Aiba $^{10} \cdot$ Rei Shibata $^{11}$. \\ Tohru Nakashizuka ${ }^{9}$. Shunsuke Managi ${ }^{1}$
}

Received: 31 August 2020 / Accepted: 26 November 2020 / Published online: 4 January 2021

(c) The Author(s) 2021, corrected publication 2021

\begin{abstract}
Recently, natural capital has gained the attention of researchers and policymakers to promote sustainability. Previous studies have investigated the value of ecosystem services with respect to specific areas or species. Other studies have investigated the value of various types of ecosystem services and natural capital by integrating a number of findings using meta-analyses at the global level. Although these studies have provided information on either the global value of natural capital or the local value of specific subjects, there is little evidence on the country-specific values of natural capital in Japan, which will provide useful information for national environmental policies. We investigated the perceived values of terrestrial and marine natural capital in Japan using internet surveys and payment card methods. Data on various natural forms of capital were collected in a unified format and comparable manner. We found that some explanatory variables, such as perceived importance and visit frequency, as well as sociodemographic characteristics, are significant drivers of the willingness to pay (WTP), which maintains each aspect of natural capital. In addition, we conducted future predictions of terrestrial and marine natural capital using a scenario developed in a previous study. Our results indicate that Japan should follow a population-dispersed scenario for the sustainable management of natural capital up to 2050 .
\end{abstract}

Keywords Terrestrial natural capital $\cdot$ Marine natural capital $\cdot$ Willingness to pay $\cdot$ Future prediction $\cdot$ Sustainable development goals

\section{Introduction}

Natural capital has gained the attention of researchers and policymakers as an essential component to promote sustainability for human well-being. In the field of sustainability science, the "strength" of sustainability depends on how we

Handled by Moinul Islam, Kyushu University, Japan.

Junya Kumagai

kumagai.jiyunya.493@s.kyushu-u.ac.jp

6 Yokosuka Headquarter, Japan Agency for Marine-Earth

Science and Technology, Kanagawa, Japan

1 Urban Institute and Department of Civil Engineering, Kyushu University, Fukuoka, Japan

2 Department of Marine Policy and Culture, Tokyo University of Marine Science and Technology, Tokyo, Japan

3 Department of Ecosystem Studies, University of Tokyo, Tokyo, Japan

4 Institute for Global Environmental Strategies, Kanagawa, Japan

7 United Nations University Institute for the Advanced Study of Sustainability, Tokyo, Japan

8 Graduate School of Engineering, Osaka University, Osaka, Japan

9 Forestry and Forest Products Research Institute, Matsunosato, Tsukuba, Japan

10 Research Institute for Humanity and Nature, Kyoto, Japan

11 Faculty of Agriculture, Niigata University, Niigata, Japan

5 Department of General Systems Studies, University of Tokyo, Tokyo, Japan 
focus on natural capital. Strong sustainability is achieved if natural capital increases during a given period while weak sustainability can be achieved if a decrease in natural capital is sufficiently compensated by an increase in other types of capital, especially produced capital (Managi and Kumar 2018; Noel and O'Connor 1998).

While the principle underlying weak sustainability is that natural capital can be substituted by other types of capital, strong sustainability assumes that there are serious limitations on the substitutability between natural capital and other types of capital (Ekins et al. 2003). In this context, the concept of critical natural capital has been proposed, which refers to natural capital that plays an essential role in supporting human well-being sustainability and cannot be substituted by other types of capital in terms of its functions. Previous studies suggest that swamps, forest ecosystems, and marine ecosystems are examples of critical natural capital (Collados and Duane 1999; Kagohashi 2017; Daisy V. MacDonald et al. 1999; Noel and O'Connor 1998).

Due to its non-substitutability, essential function, and process, these types of critical natural capital should be maintained with high priority. Nevertheless, some types of natural capital have been decreasing in recent years, especially marine and coastal natural capital, such as coral reefs, tidal flats, seaweed beds, and sand beaches. This indicates that some vital functions of natural capital that support sustainability have been deteriorating.

One effective method to prevent natural capital from declining and promote sustainability is to clarify the value of conserving these natural forms of capital. There are three main research paths that address the topic of valuing natural capital: ecosystem service valuation, inclusive wealth approach, and valuing nature's contributions to people.

A number of studies have investigated the values of natural capital by focusing on ecosystem services. Ecosystem service is a concept that clarifies and categorizes the benefits that human society derives from ecosystem functions (Costanza et al. 2017). Ecosystem services are mainly categorized into provisioning, regulating, supporting, and cultural services. Previous studies have calculated the willingness to pay (WTP) for growing or maintaining natural capital, such as forests, agricultural lands, coral reefs, oceans, and mangroves, in specific areas using stated preference methods. In addition, over the past 20 years, researchers have attempted to value natural capital at the global level (Costanza et al. 2017). These studies have investigated the value of various types of ecosystems that establish global natural capital using a meta-analysis based on the benefit transfer method (Costanza et al. 1997, 2014; de Groot et al. 2012).

The inclusive wealth index is another method for valuing natural capital (Managi and Kumar, 2018; UNU IHDP and UNEP 2014). The inclusive wealth index has been proposed to measure sustainability at global, national, and regional levels based on the sum of the total amount of produced capital, human capital, and natural capital. Some previous studies have investigated the amount of wealth at the country level (Managi and Kumar 2018), prefectural level (Ikeda and Managi 2019), and city level (Fujii and Managi 2016). In the inclusive wealth framework, the value of natural capital can be calculated by multiplying the capital stock (e.g., the total size of the area of agricultural lands) and the shadow price, which is the marginal effect that a unit of a capital stock has on intergenerational well-being. The inclusive wealth approach also includes fisheries and minerals in the natural capital calculation. However, this approach lacks certain components in the calculation, such as coastal natural capital and ecosystem services from agricultural lands.

In addition to the valuation of ecosystem services and inclusive wealth, previous studies have advocated a novel approach to understand more of the relationship between people and nature. Díaz et al. (2018) proposed the concept of nature's contributions to people (NCP). This concept attempts to capture the human-nature relationship more comprehensively by emphasizing the importance of noninstrumental, cultural perspectives, such as indigenous knowledge, norms, and beliefs, regarding how to interact with nature. The NCP concept is characterized by what constitutes the connection between nature and human well-being and how they connect. The NCP approach assumes that nature is connected with well-being through instrumental and non-instrumental values that can or cannot be measured and allowed to overlap each other.

As the concept of NCP assumes, the cultural values of natural capital are frequently bundled with other types of values. For example, in Japan, seaweed beds provide people with seaweed as food. This can be recognized as a provisioning service; however, seaweed beds simultaneously support the Japanese-specific culture of eating seaweed. In addition, within the relationship between seaweed beds and the well-being of Japanese people, there are some other processes that occur, such as harvesting seaweed, cooking dishes with seaweed, and eating them. This process may be based on Japanese-specific local knowledge, norms, and beliefs about eating seaweed. In addition, in some rural areas in Japan, forests, agricultural lands, and the lives of agricultural communities harmonize and form a Japanese-specific landscape known as a Satoyama (Saito et al. 2019). This is one example of how some types of natural capital together create cultural value, along with the provisioning services of food and timber, by harmonizing with the lives of local residents. In addition, there is a Japanese specific leisure activity known as clamming in tidal flats. We can recognize that the tidal flat is not only characterized as a food supply service of shellfish, but also the service of providing leisure. 


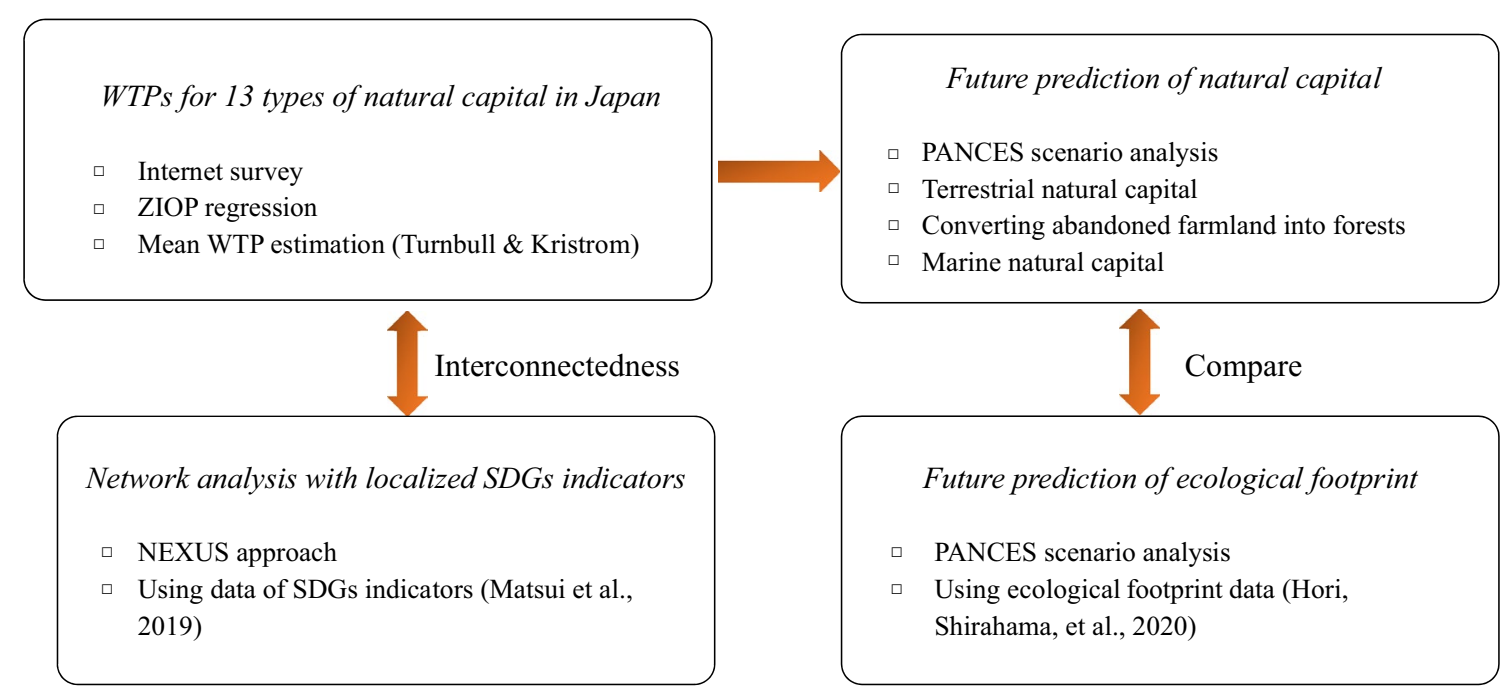

Fig. 1 Diagrams of overall framework of the analysis

These perspectives reveal that natural capital has a country-specific relationship with culture and lifestyle, such that the perceived value of a certain type of natural capital may differ from country to country. Therefore, understanding the values of natural capital in Japan at the country level and a focus on the various types of natural capital that exist in Japan are important.

In this study, we focus on the values and determinants of terrestrial and marine natural capital in Japan. We estimate Japanese households' perceived value of natural capital considering their provisioning, regulating, supporting, and cultural services, as well as some disservices. In addition, we predict the future of terrestrial natural capital in Japan at the municipality level to measure future sustainability up to 2050 based on a scenario suitable to natural capital projection (Saito et al. 2019). Simultaneously, we predict the ecological footprint in 2050 with respect to the change in the burden on the natural capital in each municipality. In addition to terrestrial natural capital, we predict the future of eelgrass beds and seaweed beds, which are main examples of marine natural capital in Japan. Furthermore, we investigate the interconnectedness between natural capital and sustainable development goals (SDGs) using a network analysis to investigate the importance of natural capital for achieving SDGs. Figure 1 shows the overall framework of our analysis.

There are several contributions from our study. First, natural capital is categorized in a more detailed manner. In many previous studies, the values have been calculated in various categories, such as agricultural lands or forests as a whole, whereas a limited number of studies consider the difference, for example, between paddy fields and crop fields and between plantation forests and natural forests. Natural forests have higher biodiversity than plantation forests
(Brockerhoff et al. 2008), which may be partly attributable to a difference in the WTP between them.

The other contribution is that we predict future projections at the municipality level, which enables us to clarify the pathways that Japanese and local governments should follow to achieve a sustainable future. Some studies have focused on the value and future of natural capital in Japan at the prefectural level (Fujii et al. 2017; Ikeda and Managi, 2019). However, a limited number of studies predict the future of natural capital at the municipality level. Focusing on the future of natural capital at the municipality level allows us to clarify the differences in the future trends in natural capital between urban and rural areas within the same prefecture. This method can reveal the disparities in terms of the impact that population decline has on the maintenance of natural capital among municipalities in urban and rural areas in Japan.

The remainder of this paper is structured as follows. In "WTP estimation for terrestrial and marine natural capital in Japan", we provide estimations of the WTP and its determinants, including an explanation of the questionnaire conducted to ask Japanese individuals about their WTP for 13 types of natural capital in Japan. In addition, the value per unit of each natural capital was estimated. "Scenarios and methodology" conducts future predictions of natural capital at the municipality level while "Prediction results" presents the results of the prediction. We predict the future of terrestrial natural capital up to 2050 in Japan by incorporating the value per unit of each natural capital estimated in "WTP estimation for terrestrial and marine natural capital in Japan" and data on the Japanese population and land use prediction (Hori et al. 2020a, b; Shoyama et al. 2019). This subsection clarifies how much future natural capital will be affected by the type of population and land use scenarios Japan will 
follow, considering the differences between urban and rural areas. "Converting abandoned agricultural lands into forests" adds one more scenario where abandoned agricultural lands will be converted into forests, analyzing the impact of this conversion on future natural capital. "Ecological footprint prediction" focuses on the ecological footprint, which sheds light on how much the burden of future consumption activities will change at the municipality level. "Eelgrass and seaweed bed prediction" predicts the future of eelgrass beds and seaweed beds in Japan, which are distributed on the coasts around Japan. "Natural capital for SDGs" investigates the relationship between natural capital and SDGs, using the scenario and data from previous studies. Although we emphasize the importance of maintaining natural capital, it is not pragmatic to focus solely on natural capital to realize sustainability. To achieve sustainability in other fields, we will clarify how natural capital is related to each item of the SDGs. The next section discusses the results of the study and provides policy implications drawn from the results.

\section{WTP estimation for terrestrial and marine natural capital in Japan}

\section{Surveyed natural capital}

We focus on 13 types of natural capital for the targets that represent the agricultural, forest, and marine natural capital in Japan, which include paddy fields, crop fields, orchards, pastures, plantation forests, natural forests, seaside protection forests, coral reefs, seaweed beds, tidal flats, sand beaches, mangrove forests, and fishing grounds. All of these play essential roles in maintaining people's lives, culture, society, environment, and well-being in Japan. However, many of them, especially marine natural capital, have been decreasing in recent years. Figure 12 shows the recent trend in the amount of each natural capital.

The cultivated area for paddy fields occupies approximately $6.6 \%$ of the land area in Japan, supporting an essential part of the food supply by producing almost $100 \%$ of the rice consumed in Japan (Natuhara 2013). Besides their role in food production, paddy fields also have critical ecosystem services, such as regulating groundwater quantity and water quality, as well as flood and soil erosion control. Furthermore, previous studies have found that paddy fields maintain biodiversity by providing wetland habitats for many species, such as fish (Katano et al. 2003), insects (Mukai et al. 2005), frogs (Fujioka and Lane 1997), and other wild animals (Natuhara 2013). In contrast, paddies are also habitats for carriers of infectious diseases, such as mosquitos and ixodid ticks, which are possible vectors of Japanese encephalitis virus and SFTS virus, respectively (Kato et al. 2016; T. Tsunoda and Mori 2000; Umenai et al. 1985). Rice-paddy acreage has been decreasing for at least the last five decades, with 1.58 million hectares in 2014.

The cultivated area for crop fields, orchards, and pastures is equivalent to $5.3 \%$ of the land area in Japan (MAFF 2018). These agricultural lands play a role in producing wheat, barley, vegetables, beans, fruit, and pasture plants. They also have regulating services, such as water and soil control, and provide habitats for wild species, including mosquitos and ixodid ticks. The planted areas for crops, fruit, and forage/ manure crops were 980, 230, and 1.02 million ha, respectively, in 2014.

The overall forest area in Japan is approximately 2.5 million hectares, which is equivalent to $67 \%$ of the land area (MAFF 2017). Of the total forest area in Japan, plantation forests account for $41 \%$ and natural forests ${ }^{1}$ account for $54 \%$. Forests play a role mainly in producing timber, as well as in constructing habitats for various species, providing soil nutrients, preventing sediment disasters, controlling climate, and regulating water quality and quantity (Forestry Agency of Japan 2010). Compared with plantation forests, natural forests usually maintain a higher level of biodiversity (Brockerhoff et al. 2008). In addition to these functions and benefits of forests, seaside protection forests play a vital role as a windbreak and preventing damage from tsunamis, storm surges, and salt pollution. Forests provide us with recreational sites for therapeutic walks, wild plant picking, and picnics. In contrast, forests are also habitats for hornet, ixodid, and wild animals that ravage crop fields.

Natural marine capital contributes mainly to the conservation of coastal biodiversity, the construction of habitats for various species, and providing people with a variety of food, such as fish, crab, shrimp, shellfish, and seaweed (Fisheries Agency of Japan 2008; MOE 2007; Spalding et al. 2010). Each marine and coastal natural capital contributes to sustainability by providing nursery areas for juvenile fish, climate control, water quality improvement, and coastline protection. Furthermore, marine and coastal natural capital contributes to residential well-being from a cultural perspective by providing us with places for recreation activities, such as swimming, diving, and snorkeling. In addition, seaweed beds support the unique Japanese food culture, such as eating sea urchins, kelp, and seaweed. Although marine natural capital sustains the well-being of people in Japan from the various aspects mentioned above, there are declining trends in marine natural capital (Fig. 12).

\footnotetext{
${ }^{1}$ Natural forests are forests that have reproduced naturally and are composed of indigenous tree species. For details on the definition of natural forests established by the Japanese government, see Forestry Agency of Japan (2017).
} 


\section{Data}

To estimate the WTP to maintain the targeted natural capital and identify its determinants, we used data from a survey that we originally conducted in Japan in February 2019. Through the internet, a sample of 7556 Japanese individuals was collected. The aim of the survey was to investigate the value of various types of natural capital, consistent with the natural and agricultural environment of land and ocean in Japan. We asked respondents about their WTP to maintain each natural capital using payment card methods. The question about WTP included the 13 types of natural capital mentioned in the previous subsection. We additionally asked the respondents about their WTP to maintain overall natural environment in Japan to estimate the maximum amount of money that an average Japanese household can pay for the entire environmental conservation project in Japan. We also asked questions about respondents' behavior and perception that appeared to be the explanatory variables of the WTP values.

The wording of the questions on WTP were as follows: "How much is the maximum amount that you can pay annually from your household to maintain X?", where X is one of the 13 natural capital aspects mentioned above. The respondents selected one of the ranges displayed on the screen. Before selecting their WTP for each natural capital, the respondents were shown bar charts of the recent changes in the amount of natural capital (Fig. 12), a list of the ecosystem services provided by natural capital, and hypothetical amounts of decreases in natural capital without the implementation of a hypothetical project to maintain each natural capital (Table 7). Provisioning, regulating, supporting, and cultural services were included in the information on the ecosystem services of each natural capital.

We also provided some additional assumptions about hypothetical projects. First, when responding to payment for each natural capital, we assumed that the respondents have not paid for other natural capital. Second, the money that the respondents pay will be used only for the project to maintain each natural capital. Third, if the project will be conducted, not only the agreed household, but also all households will pay through taxes and price increases on relevant goods, among others. Finally, we assumed that the payments will continue for the next 10 years.

Furthermore, if respondents selected 0 JPY as their WTP for all of the items that we asked, they were asked why they did not want to pay. A certain percentage of the respondents selected the following: "I think I do not have any obligation to pay," "I'm worried about whether the money I paid will be used correctly," "I cannot decide from the information given," or "other." We identified these responses as protest responses. We excluded protest responses from our analysis.
Figure 2 shows the distributions of the responses for the WTPs.

In addition, we questioned the frequency of visiting each natural capital and the perceived importance of each natural capital. These personal behaviors and perceptions related to natural capital appear to affect the WTP to maintain natural capital. Table 1 lists how frequently the respondents visit each natural capital. Table 2 summarizes the perceived importance of each natural capital.

Table 2 summarizes the other explanatory variables. We asked questions on the respondents' sociodemographic characteristics, such as gender, age, and household income, to utilize their answers as the explanatory variables for the WTP. We excluded respondents who selected "do not know" or "do not want to answer" in terms of their household income from our analytical sample. We also asked the respondents to report their residential area using an 8-digit regional mesh code based on standard grid squares (1 $\mathrm{km} \times 1 \mathrm{~km}$ resolution).

As an additional explained variable, we constructed a dummy variable that equals 1 if the respondent lives in an urban area. We regarded the municipalities whose populations are over 200,000 and daytime/nighttime population ratios of more than 0.98 as central cities while classifying central cities and their adjacent municipalities as urban areas. These areas are recognized as the places where future populations will concentrate if Japan forms a compact society (Hori et al. 2020a, b). We also defined municipalities other than urban areas as rural areas. Approximately $60 \%$ of the respondents lived in urban areas.

To examine the relationship between geospatial variables and WTP, we combined secondary geospatial data from MLIT (2014) and MOE (2005) with the sample of our survey data. Specifically, we used the areas of paddy fields, other agricultural lands, and forests within $1 \mathrm{~km}$ grids in which the respondents' residences exist, as well as the distances to the nearest coral reefs, seaweed beds, tidal flats, sand beaches, mangrove forests, and coastal lines from the respondents' residences. Using these variables, we can test the hypothesis that the WTP to maintain each natural capital differs depending on whether the corresponding natural capital exists near the respondents' residential areas. Moreover, to consider whether there are regional differences in the WTP, we employed a frequently used Japanese regional classification, referred to as the eight regions, which divides Japan into Hokkaido, Tohoku, Kanto, Chubu, Kinki, Chugoku, Shikoku, and Kyushu/Okinawa.

Furthermore, we included City Biodiversity Index (CBI) data from MLIT (2016), which evaluates current situations in terms of the biodiversity at the municipality level and the extent to which the residents and local government in each municipality are active in the conservation of biodiversity. There are seven types of indices depending on we assess 


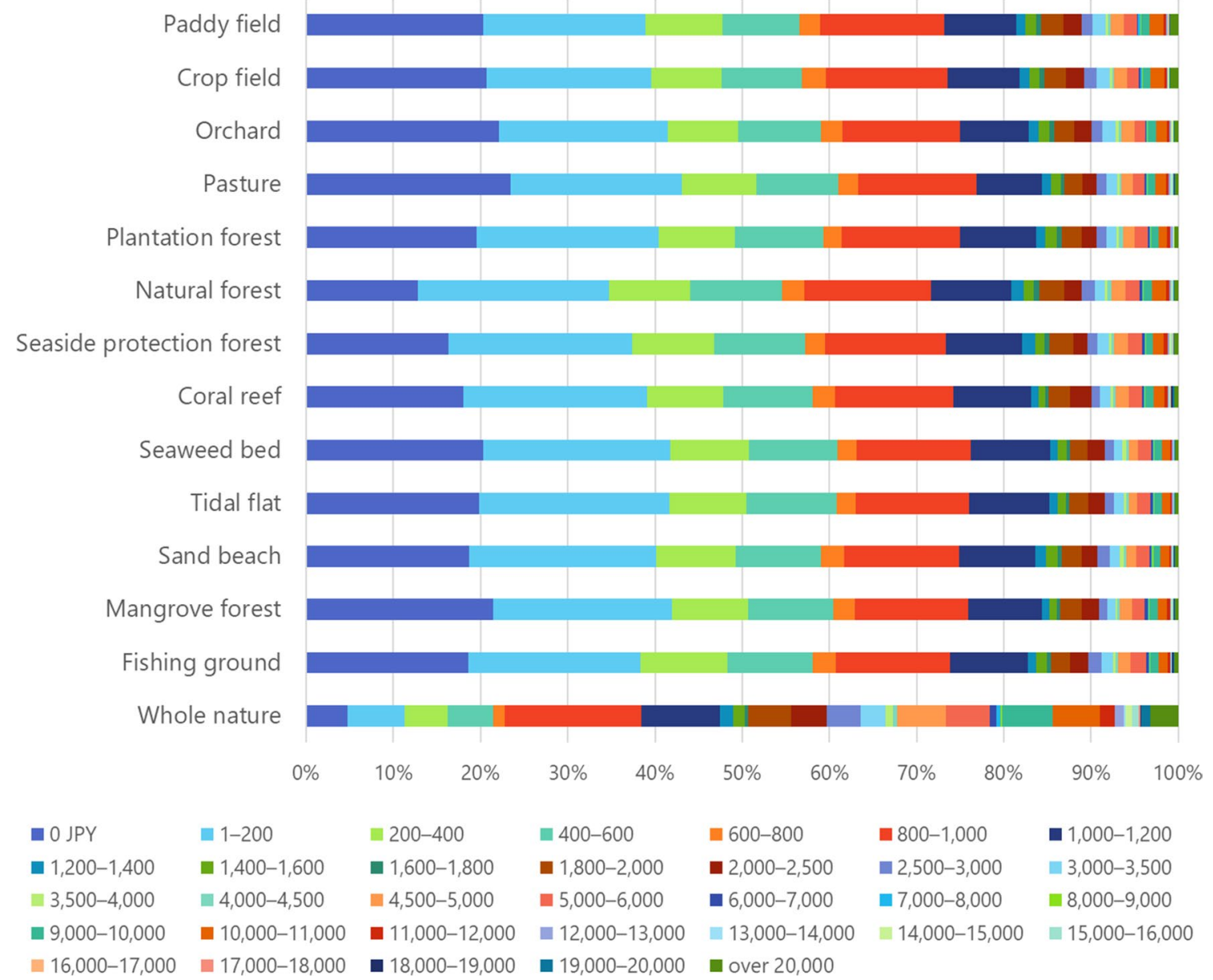

Fig. 2 Distribution of the response to WTP questions

Table 1 Frequency of visiting each natural capital

\begin{tabular}{|c|c|c|c|c|c|c|}
\hline Frequency of visits (\%) & Paddy field & Crop field & Orchard & Pasture & Forest & Coral reef \\
\hline Pass through sometimes & 59.7 & 57.8 & 44.8 & 35.1 & 43.7 & 10.2 \\
\hline Less than once a year & 5.0 & 5.3 & 14.2 & 11.7 & 10.2 & 10.9 \\
\hline Once a year-once a month & 5.1 & 6.2 & 5.6 & 3.7 & 7.9 & 2.2 \\
\hline Once a month-once a week & 2.4 & 4.0 & 2.0 & 1.5 & 3.7 & 0.6 \\
\hline Once a week-three times a week & 1.6 & 3.5 & 1.0 & 0.6 & 1.7 & 0.5 \\
\hline Three times a week-everyday & 1.2 & 2.1 & 0.4 & 0.3 & 0.8 & 0.2 \\
\hline Never been & 24.9 & 21.0 & 32.0 & 47.2 & 32.0 & 75.4 \\
\hline Frequency of visits (\%) & Seaweed bed & Tidal flat & Sand beach & \multicolumn{2}{|c|}{ Mangrove forest } & Sea (offshore) \\
\hline Pass through sometimes & 10.1 & 13.8 & 23.6 & 7.0 & & 19.7 \\
\hline Less than once a year & 6.8 & 11.2 & 27.3 & 7.0 & & 24.4 \\
\hline Once a year-once a month & 1.7 & 2.9 & 12.9 & 1.2 & & 8.1 \\
\hline Once a month-once a week & 1.0 & 0.7 & 2.3 & 0.7 & & 2.2 \\
\hline Once a week-three times a week & 0.5 & 0.5 & 0.9 & 0.3 & & 0.6 \\
\hline Three times a week-everyday & 0.2 & 0.3 & 0.4 & 0.1 & & 0.3 \\
\hline Never been & 79.8 & 70.7 & 32.7 & 83.8 & & 44.7 \\
\hline
\end{tabular}


Table 2 Summary statistics $\left(n=3208^{\mathrm{b}}\right)$

\begin{tabular}{|c|c|}
\hline Variable & Mean value or $\%$ value \\
\hline$\%$ Female & $46.4 \%$ \\
\hline$\%$ University graduate & $54.4 \%$ \\
\hline$\%$ Worker (incl. full-time and part-time) & $74.5 \%$ \\
\hline$\%$ Urban & $61.8 \%$ \\
\hline Average age (M/SD) & $44.7 / 13.2$ \\
\hline Average household size (M/SD) & $2.7 / 1.3$ \\
\hline Average number of children (M/SD) & $0.47 / 0.85$ \\
\hline \multicolumn{2}{|l|}{ Annual household income } \\
\hline$<2$ million JPY & $9.2 \%$ \\
\hline 2-3 million JPY & $9.0 \%$ \\
\hline 3-4 million JPY & $13.3 \%$ \\
\hline 4-5 million JPY & $13.1 \%$ \\
\hline 5-6 million JPY & $12.1 \%$ \\
\hline 6-7 million JPY & $9.9 \%$ \\
\hline 7-8 million JPY & $8.8 \%$ \\
\hline 8-9 million JPY & $5.9 \%$ \\
\hline 9-10 million JPY & $6.6 \%$ \\
\hline 10-15 million JPY & $8.8 \%$ \\
\hline 15-20 million JPY & $2.1 \%$ \\
\hline 20-30 million JPY & $1.0 \%$ \\
\hline$\geq 30$ million JPY & $0.3 \%$ \\
\hline \multicolumn{2}{|l|}{ Items that respondents perceive as important } \\
\hline$\%$ Paddy field & $48.6 \%$ \\
\hline$\%$ Crop field & $31.1 \%$ \\
\hline$\%$ Orchard & $7.8 \%$ \\
\hline$\%$ Pasture & $4.3 \%$ \\
\hline$\%$ Plantation forest & $15.0 \%$ \\
\hline$\%$ Natural forest & $46.3 \%$ \\
\hline$\%$ Seaside protection forest & $13.1 \%$ \\
\hline$\%$ Coral reef & $20.1 \%$ \\
\hline$\%$ Seaweed bed & $6.0 \%$ \\
\hline$\%$ Tidal flat & $8.7 \%$ \\
\hline$\%$ Sand beach & $9.5 \%$ \\
\hline$\%$ Mangrove forest & $4.4 \%$ \\
\hline$\%$ Fishing ground & $28.9 \%$ \\
\hline \multicolumn{2}{|l|}{ Average area of each NC in $1 \mathrm{~km}^{2} \operatorname{grid}\left(\mathrm{m}^{2}\right)$} \\
\hline Paddy field (M/SD) & $75,755.8 / 156,950.2$ \\
\hline Other agricultural land (M/SD) & $33,796.5 / 85,201.9$ \\
\hline Forest (M/SD) & $83,794.2 / 170,842.1$ \\
\hline \multicolumn{2}{|c|}{ Average distance to each $\mathrm{NC}$ from residents (km) } \\
\hline Coral reef $(\mathrm{M} / \mathrm{SD})$ & $183.7 / 228.7$ \\
\hline Seaweed bed (M/SD) & $30.9 / 26.1$ \\
\hline Tidal flat (M/SD) & $41.0 / 47.3$ \\
\hline Sand beach (M/SD) & $18.9 / 22.5$ \\
\hline Mangrove forest (M/SD) & $851.8 / 378.8$ \\
\hline Coastal line (M/SD) & $18.3 / 23.4$ \\
\hline \multicolumn{2}{|l|}{ The area respondents live in } \\
\hline$\%$ Hokkaido & $8.5 \%$ \\
\hline$\%$ Tohoku & $8.7 \%$ \\
\hline$\%$ Kanto & $24.0 \%$ \\
\hline
\end{tabular}

Table 2 (continued)

\begin{tabular}{ll}
\hline Variable & Mean value or \% value \\
\hline$\%$ Chubu & $18.3 \%$ \\
$\%$ Kinki & $12.6 \%$ \\
$\%$ Chugoku & $9.8 \%$ \\
$\%$ Shikoku & $3.5 \%$ \\
\% Kyushu/Okinawa & $14.6 \%$ \\
City Biodiversity Index (CBI) & \\
Score 4 & $54.7 / 11.1$ \\
Score 6 & $57.6 / 12.5$ \\
Score 7 & $56.6 / 10.9$ \\
\hline
\end{tabular}

a JPY (Japanese Yen) approximately equal to USD 0.009

${ }^{\mathrm{b}}$ After the cleaning and data combination processes, we obtained 3208 observations

biodiversity and related activities. Out of the seven indices, we used scores 4,6 , and 7 , which are calculated using local governments' answers to a questionnaire on biodiversityrelated activities. Score 4 assesses how actively each local government conducts surveys of the number of animals and plants inhabiting their territory. Score 6 measures how much each local government considers biodiversity conservation in their city planning. Score 7 evaluates how much each local government encourages residents and organizations in their area to participate in activities related to biodiversity conservation. ${ }^{2}$ These scores have standardized values with averages of 50 and standard deviations of ten among Japanese municipalities. We assigned the scores of the corresponding municipality to each respondent depending on where the respondent lives. Using these data, we can examine the relationship between the WTP for natural capital and how active local governments and residents are in biodiversity conservation.

\section{Estimation method}

We analyzed the determinants of the WTP to maintain the 13 types of natural capital, along with maintaining the entirety of the natural environment, as it currently stands in Japan. Even after removing the protest responses from the analytical sample, approximately $20 \%$ of the respondents still showed zero WTP for most of the items, except for the overall nature of Japan.

Recent empirical studies have applied the zero-inflated ordered probit (ZIOP) model to ordinal dependent variables (Harris and Zhao 2007). Some studies have shown the superiority of the ZIOP regression as opposed to the

\footnotetext{
${ }^{2}$ For more detailed information on the City Biodiversity Index, see
} MLIT (2016). 
traditional ordered probit to provide less biased estimates when an ordinal dependent variable exhibits a high fraction of observations at zero (Bagozzi et al. 2012). These studies explain that the ZIOP model is preferred when the zeros are related to two distinct sources: one is referred to as an "always-zero" observation (e.g., a person who never pays for a certain natural capital, even if their income increases) and the other is a zero observation that may transition into a non-zero value (e.g., a person who might pay if their income increases). As the determinants of being an always-zero person are often different from the determinants of how much a person will pay, the standard ordered probit model that does not consider the always-zero observation cannot precisely estimate such a situation.

This model assumed two latent dependent variables through the estimation process. The latent variable model is represented by the following equations:

$r^{*}=x^{\prime} \beta+\varepsilon$,

$y^{*}=z^{\prime} \gamma+u$,

and

$y= \begin{cases}0 & \text { if } r^{*} \leq 0 \text { or } y^{*} \leq 0, \\ j & \text { if } 0<r^{*} \text { and } \mu_{j-1}<y^{*} \leq \mu_{j}(j=1, \ldots, J-1), \\ J & \text { if } 0<r^{*} \text { and } \mu_{J-1}<y^{*}\end{cases}$

where $r^{*}$ is a latent variable representing the propensity to participate in the WTP decision, $x$ is a vector of determinants for participation with unknown parameters, $\beta, y^{*}$ is a latent variable related to an ordinal variable, $y$, taking the values $\{0,1,2, \ldots, J\}, z$ is a vector of determinants of $y$ with unknown parameters, $\gamma$. The terms $\varepsilon$ and $u$ are standard normally distributed errors, and $\mu_{j}(j=1, \ldots, J-1)$ are unknown threshold parameters. The unknown parameters can be estimated by maximum likelihood estimation. As explanatory variables $x$ and $z$, we include the sociodemographic variables described in the previous section. Equation (1) is a splitting equation that estimates the effects that covariates have on the probabilities of not being always-zero observations while Eq. (2) is an outcome equation that estimates the effects that the covariates have on the amount of the objective variable (Bagozzi et al. 2012).

In addition, we obtained two types of mean WTP estimations using our survey data. For the payment card method, there are two types of WTP estimations that have been frequently used in previous studies (Blaine et al. 2005). One is the Turnbull lower bound mean (LBM), which is calculated as follow:
$\mathrm{LBM}=\pi_{0} p_{0}+\sum_{i=1}^{k} \pi_{i}\left(p_{i}-p_{i-1}\right)$,

where $\pi_{i}$ are the cumulative percentages of respondents who select the range of monetary value less than $p_{i+1}$ and $p_{0}$ is the initial bid price (Turnbull, 1976). The other WTP estimation method is the Kristrom mean (Kriström 1990), which is calculated as follows:

Kristrom mean $=\mathrm{LBM}+\frac{p_{0}\left(1-\pi_{0}\right)}{2}$
$+\sum_{i=1}^{k}\left\{\frac{\left|\pi_{i}-\pi_{i-1}\right|\left(p_{i}-p_{i-1}\right)}{2}\right\}+\frac{\pi_{k}\left(p^{*}-p_{k}\right)}{2}$,

where $p^{*}$ is the estimated price for each natural capital when $\pi$, the percentage that respondents pay, $p$, to maintain the natural capital, is equal to zero. An OLS regression of $\pi_{i}$ on the natural $\log$ of $p_{i}$ for each natural capital was conducted to obtain the predicted value of $p^{*}$, considering that there is an approximately linear relationship between $\pi_{i}$ and $\ln \left(p_{i}\right)$ in our data. Kristrom's measure provides higher WTP estimates than LBM because the former assumes the distribution of the WTP between bid prices, but the latter uses lower bid prices without any assumption of the WTP distribution between bid prices (Lee et al. 2015).

\section{Regression results}

Table 3 lists the results of the regression. The coefficients of the outcome equation can be interpreted as the effects that the explanatory variables have on the WTP amounts while the coefficients of the splitting equation imply the effects of the variables on the probabilities that the respondents are willing to pay more than zero.

In the splitting equation, the variables of gender, living urban areas, visit frequency, and perceived importance are significant determinants of the WTP for many natural capital categories. We found that female respondents are more likely to be willing to pay to maintain all 13 natural capital categories than males. Residents in urban areas tend not to pay to maintain some natural capital and the entire nature of Japan compared with residents in rural areas. The visit frequency, perceived importance, or both positively affected the WTP for most of the natural capital categories, except for orchards and pastures. In addition, the elderly are more likely to pay for some marine natural capital and the overall environment than younger people. In terms of the geospatial variables, only the areas of forests within a $1 \mathrm{~km}$ grid where respondents live positively affects the probability of the WTP for natural forest maintenance. The coefficients of the eight region dummies are mostly negative, where some are statistically significant, 
Table 3 ZIOP regression results

\begin{tabular}{|c|c|c|c|c|c|c|c|}
\hline Variable & Paddy & Crop & Orchard & Pasture & Plantation forest & Natural forest & Seaside forest \\
\hline \multicolumn{8}{|l|}{ Outcome Eq } \\
\hline Female & $-0.157^{* * *}$ & $-0.166^{* * *}$ & $-0.163^{* * *}$ & $-0.130^{* *}$ & $-0.0932^{* *}$ & -0.0696 & $-0.0883^{*}$ \\
\hline Age & -0.00107 & -0.00119 & $-0.00320^{*}$ & -0.00115 & -0.00276 & -0.00252 & -0.00276 \\
\hline Graduate & 0.0686 & 0.0813 & 0.0754 & 0.0821 & 0.0618 & $0.0815^{*}$ & 0.0709 \\
\hline Household size & -0.0347 & -0.0272 & -0.0311 & -0.0383 & $-0.0506^{* *}$ & -0.0347 & -0.0324 \\
\hline Child & 0.0412 & 0.0411 & 0.0413 & 0.0511 & 0.0517 & 0.0421 & 0.0273 \\
\hline Worker & -0.000418 & 0.0164 & 0.0179 & 0.0248 & -0.0506 & -0.0123 & -0.0369 \\
\hline Income & $0.000448^{* * * *}$ & $0.000452^{* * * *}$ & $0.000460^{* * * *}$ & $0.000433^{* * *}$ & $0.000420^{* * * *}$ & $0.000401^{* * * *}$ & $0.000419^{* * * *}$ \\
\hline Urban & -0.000390 & 0.000828 & -0.0173 & -0.00785 & 0.0232 & -0.00990 & 0.00509 \\
\hline Visit & $0.159^{* * *}$ & $0.140^{* * *}$ & $0.185^{* * *}$ & $0.203^{* * *}$ & $0.0904^{* * *}$ & $0.111^{* * *}$ & $0.105^{* * *}$ \\
\hline Importance & $0.180^{* * * *}$ & $0.130^{* * *}$ & -0.00637 & -0.135 & 0.0553 & $0.0859^{* *}$ & 0.0821 \\
\hline Area of paddy field & $1.79 \mathrm{e}-07$ & & & & & & \\
\hline Area of agricultural land & & $-4.62 \mathrm{e}-07$ & $-4.12 \mathrm{e}-07$ & $-2.33 \mathrm{e}-07$ & & & \\
\hline Area of forest & & & & & $4.08 \mathrm{e}-08$ & $-1.94 \mathrm{e}-08$ & $1.20 \mathrm{e}-08$ \\
\hline Distance to coastal line & & & & & & & $-0.0471^{* *}$ \\
\hline \multicolumn{8}{|l|}{ Hokkaido area (baseline) } \\
\hline Tohoku area & $-0.369^{* * *}$ & $-0.320^{* * *}$ & $-0.304^{* * *}$ & $-0.312^{* * *}$ & $-0.280^{* * *}$ & $-0.276^{* * *}$ & $-0.261^{* *}$ \\
\hline Kanto area & $-0.201^{* *}$ & $-0.188^{* *}$ & $-0.178^{*}$ & -0.151 & $-0.150^{*}$ & -0.124 & $-0.164^{*}$ \\
\hline Chubu area & $-0.279^{* * *}$ & $-0.262^{* * *}$ & $-0.186^{*}$ & $-0.181^{*}$ & $-0.160^{*}$ & -0.137 & $-0.184^{* *}$ \\
\hline Kinki area & $-0.248^{* *}$ & $-0.237^{* *}$ & $-0.208^{*}$ & -0.146 & $-0.182^{*}$ & $-0.180^{*}$ & $-0.198^{* *}$ \\
\hline Chugoku area & $-0.361^{* * *}$ & $-0.338^{* * *}$ & $-0.305^{* * *}$ & $-0.297^{* * *}$ & $-0.275^{* *}$ & $-0.226^{* *}$ & $-0.336^{* * *}$ \\
\hline Shikoku area & $-0.401^{* * *}$ & $-0.303^{* *}$ & -0.231 & -0.196 & -0.233 & $-0.248^{*}$ & $-0.316^{* *}$ \\
\hline Kyushu/Okinawa area & $-0.228^{* *}$ & $-0.214^{* *}$ & $-0.206^{* *}$ & $-0.225^{* *}$ & $-0.223^{* *}$ & $-0.209^{* *}$ & $-0.262^{* * *}$ \\
\hline CBI score 4 & -0.00328 & -0.00254 & -0.00302 & $-0.00402^{*}$ & -0.00185 & -0.00240 & -0.000509 \\
\hline CBI score 6 & -0.00470 & -0.00457 & -0.00533 & -0.00395 & -0.00110 & -0.00187 & -0.00290 \\
\hline CBI score 7 & $0.00672^{*}$ & 0.00541 & $0.00703^{*}$ & 0.00540 & 0.000764 & 0.00167 & 0.00184 \\
\hline \multicolumn{8}{|l|}{ Splitting Eq } \\
\hline Female & $0.534^{* * *}$ & $0.760^{* *}$ & $0.614^{* * *}$ & $0.740^{* * *}$ & $0.314^{* *}$ & $0.281^{* * *}$ & $0.322^{* * *}$ \\
\hline Age & -0.00314 & -0.00659 & -0.00468 & -0.00657 & 0.00552 & 0.00253 & 0.00388 \\
\hline Graduate & 0.105 & 0.0185 & -0.00603 & -0.0755 & $0.121^{*}$ & 0.102 & 0.113 \\
\hline Household size & 0.0598 & 0.0847 & 0.0714 & $0.1000^{*}$ & 0.0412 & 0.00708 & -0.00639 \\
\hline Child & 0.0329 & 0.0144 & 0.0745 & 0.0224 & -0.00755 & -0.0108 & 0.0344 \\
\hline Worker & 0.00964 & 0.0134 & -0.0268 & -0.0907 & 0.0542 & -0.0493 & 0.0181 \\
\hline Income & -0.000137 & -0.000172 & $-0.000207^{*}$ & $-0.000204^{*}$ & $-4.78 \mathrm{e}-05$ & $5.53 \mathrm{e}-05$ & $-1.64 \mathrm{e}-05$ \\
\hline Urban & $-0.155^{*}$ & $-0.193^{*}$ & -0.117 & -0.176 & -0.0921 & -0.123 & -0.102 \\
\hline Visit & $0.0767^{* *}$ & 0.0414 & 0.0247 & 0.0479 & $0.140^{* * *}$ & $0.201^{* * *}$ & $0.144^{* * *}$ \\
\hline Importance & $0.720^{* * *}$ & $0.373^{* * *}$ & -0.0814 & 0.393 & $0.566^{* *}$ & $0.568^{* * *}$ & $0.371^{\text {*** }}$ \\
\hline Area of paddy field & $7.56 \mathrm{e}-09$ & & & & & & \\
\hline Area of agricultural land & & $8.78 \mathrm{e}-07$ & $4.34 \mathrm{e}-07$ & $1.09 \mathrm{e}-07$ & & & \\
\hline Area of forest & & & & & $1.88 \mathrm{e}-07$ & $7.19 \mathrm{e}-07^{* *}$ & $4.54 \mathrm{e}-07$ \\
\hline Distance to coastal line & & & & & & & -0.0163 \\
\hline \multicolumn{8}{|l|}{ Hokkaido area (baseline) } \\
\hline Tohoku area & -0.198 & -0.136 & -0.0984 & -0.0240 & -0.171 & -0.263 & -0.224 \\
\hline Kanto area & $-0.307^{*}$ & -0.368 & -0.363 & -0.297 & $-0.240^{*}$ & $-0.346^{* *}$ & $-0.288^{* *}$ \\
\hline Chubu area & -0.290 & -0.225 & -0.323 & -0.303 & -0.193 & -0.229 & $-0.247^{*}$ \\
\hline Kinki area & $-0.467^{* *}$ & $-0.509^{*}$ & $-0.473^{*}$ & $-0.607^{* *}$ & $-0.375^{* *}$ & $-0.477^{* * *}$ & $-0.397^{* * *}$ \\
\hline Chugoku area & $-0.413^{* *}$ & -0.373 & $-0.500^{*}$ & -0.456 & -0.255 & $-0.537^{* * *}$ & $-0.342^{* *}$ \\
\hline Shikoku area & -0.308 & $-0.542^{*}$ & $-0.567^{*}$ & -0.474 & -0.281 & $-0.526^{* *}$ & $-0.360^{*}$ \\
\hline Kyushu/Okinawa area & -0.223 & -0.310 & -0.296 & -0.146 & -0.117 & -0.137 & -0.0171 \\
\hline CBI score 4 & 0.00317 & 0.00246 & 0.00313 & 0.00392 & 0.00189 & 0.00425 & $3.79 \mathrm{e}-05$ \\
\hline
\end{tabular}


Table 3 (continued)

\begin{tabular}{|c|c|c|c|c|c|c|c|}
\hline Variable & Paddy & Crop & Orchard & Pasture & Plantation forest & Natural forest & Seaside forest \\
\hline CBI score 6 & $0.0133^{* *}$ & $0.0167^{* *}$ & $0.0133^{*}$ & $0.0141^{*}$ & 0.00577 & 0.00544 & 0.00351 \\
\hline CBI score 7 & $-0.0168^{* *}$ & $-0.0191^{* *}$ & $-0.0181^{* *}$ & $-0.0170^{* *}$ & $-0.00972^{* *}$ & $-0.0136^{* *}$ & -0.00510 \\
\hline Constant & $0.902^{* *}$ & $1.377^{* * *}$ & $1.576^{* * *}$ & $1.532^{* * * *}$ & $0.522^{*}$ & $1.047^{* * *}$ & $0.890^{* * *}$ \\
\hline Observations & 3103 & 3104 & 3095 & 3093 & 3107 & 3116 & 3111 \\
\hline Variable & Coral reef & Seaweed bed & Tidal flat & Sand beach & Mangrove & Fishing ground & Whole nature \\
\hline \multicolumn{8}{|l|}{ Outcome Eq } \\
\hline Female & -0.0447 & $-0.0967^{* *}$ & $-0.0998^{* *}$ & $-0.139^{* * *}$ & -0.0155 & $-0.137^{* * *}$ & $-0.0882^{* *}$ \\
\hline Age & 0.000958 & -0.00191 & $-0.00345^{*}$ & -0.00201 & 0.00111 & -0.00124 & $0.00278^{*}$ \\
\hline Graduate & $0.0892^{* *}$ & $0.0826^{*}$ & $0.0915^{*}$ & 0.0442 & $0.139^{* * * *}$ & $0.0856^{*}$ & $0.107^{* * *}$ \\
\hline Household size & $-0.0442^{* *}$ & $-0.0462^{* *}$ & -0.0346 & $-0.0363^{*}$ & $-0.0589^{* *}$ & $-0.0409^{*}$ & $-0.0421^{* *}$ \\
\hline Child & $0.0781^{* *}$ & $0.0548^{*}$ & 0.0344 & 0.0384 & $0.0619^{*}$ & 0.0384 & $0.0546^{*}$ \\
\hline Worker & -0.0104 & 0.0294 & 0.0587 & 0.0748 & -0.0224 & 0.0480 & 0.0315 \\
\hline Income & $0.000389^{* * *}$ & $0.000411^{* * * *}$ & $0.000442^{* * * *}$ & $0.000364^{* * * *}$ & $0.000413^{* * *}$ & $0.000380^{* * *}$ & $0.000550^{* * *}$ \\
\hline Urban & 0.000487 & -0.0279 & -0.0166 & -0.0144 & 0.0238 & 0.00322 & -0.0191 \\
\hline Visit & $0.167^{* * *}$ & $0.156^{* * *}$ & $0.0893^{* * *}$ & $0.112^{* * *}$ & $0.171^{* * *}$ & $0.0879^{* * * *}$ & \\
\hline Importance & 0.0375 & 0.0797 & $0.216^{* * *}$ & -0.0397 & $0.287^{* * *}$ & $0.126^{* * *}$ & \\
\hline Distance to coral reef & 0.000753 & & & & & & \\
\hline Distance to seaweed bed & & -0.0236 & & & & & \\
\hline Distance to tidal flat & & & 0.0302 & & & & \\
\hline Distance to sand beach & & & & -0.0282 & & & \\
\hline Distance to mangrove forest & & & & & $0.0927^{*}$ & & \\
\hline Distance to coastal line & -0.0235 & & $-0.0535^{*}$ & & $-0.0532^{* *}$ & $-0.0434^{*}$ & \\
\hline \multicolumn{8}{|l|}{ Hokkaido area (baseline) } \\
\hline Tohoku area & $-0.245^{* *}$ & $-0.275^{* *}$ & $-0.285^{* *}$ & $-0.266^{* *}$ & $-0.260^{* *}$ & $-0.239^{* *}$ & $-0.233^{* *}$ \\
\hline Kanto area & -0.146 & -0.117 & -0.113 & -0.128 & -0.0530 & -0.131 & $-0.161^{* *}$ \\
\hline Chubu area & -0.147 & $-0.152^{*}$ & $-0.175^{*}$ & $-0.178^{* *}$ & -0.128 & $-0.241^{* *}$ & $-0.200^{* *}$ \\
\hline Kinki area & -0.181 & -0.167 & -0.172 & $-0.206^{* *}$ & -0.0410 & $-0.247^{* *}$ & $-0.209^{* *}$ \\
\hline Chugoku area & $-0.258^{* *}$ & $-0.247^{* *}$ & $-0.243^{* *}$ & $-0.264^{* * * *}$ & -0.0587 & $-0.331^{* * *}$ & -0.150 \\
\hline Shikoku area & $-0.307^{* *}$ & -0.205 & -0.228 & -0.222 & -0.180 & $-0.290^{*}$ & $-0.240^{*}$ \\
\hline Kyushu/Okinawa area & $-0.248^{* *}$ & $-0.272^{* * *}$ & $-0.304^{* * *}$ & $-0.307^{* * *}$ & -0.138 & $-0.353^{* * *}$ & -0.135 \\
\hline CBI score 4 & -0.00257 & -0.00233 & -0.00168 & -0.00106 & -0.00301 & -0.00271 & -0.00130 \\
\hline CBI score 6 & $-0.00725^{* *}$ & -0.00184 & -0.00159 & -0.00238 & $-0.00694^{* *}$ & -0.00343 & 0.000258 \\
\hline CBI score 7 & 0.00552 & 0.00344 & 0.00198 & 0.00258 & 0.00582 & 0.00451 & -0.00186 \\
\hline \multicolumn{8}{|l|}{ Splitting Eq } \\
\hline Female & $0.277^{* * *}$ & $0.321^{* * *}$ & $0.345^{* * *}$ & $0.208^{* * *}$ & $0.525^{* * *}$ & $0.326^{* * *}$ & 0.231 \\
\hline Age & $0.00400^{*}$ & $0.00477^{* *}$ & $0.00689^{* *}$ & $0.00511^{* *}$ & 0.00629 & 0.00207 & $0.0156^{* * *}$ \\
\hline Graduate & 0.0887 & $0.113^{*}$ & 0.0690 & $0.121^{* *}$ & -0.105 & $0.126^{*}$ & -0.177 \\
\hline Household size & 0.0356 & 0.0280 & 0.0193 & 0.0258 & $0.167^{* *}$ & 0.0425 & 0.116 \\
\hline Child & -0.0292 & -0.0166 & 0.000491 & -0.00991 & -0.0757 & 0.0147 & -0.169 \\
\hline Worker & 0.000497 & -0.0380 & -0.0871 & -0.0642 & 0.0297 & -0.0856 & 0.0113 \\
\hline Income & $8.82 \mathrm{e}-05$ & $7.38 \mathrm{e}-05$ & $5.84 \mathrm{e}-05$ & $0.000127^{*}$ & -0.000189 & $-9.41 \mathrm{e}-05$ & $-2.38 \mathrm{e}-05$ \\
\hline Urban & -0.0695 & $-0.151^{* *}$ & $-0.188^{* * *}$ & $-0.153^{* * *}$ & -0.115 & $-0.213^{* *}$ & $-0.428^{* * *}$ \\
\hline Visit & $0.146^{* * *}$ & $0.101^{* * *}$ & $0.172^{* * *}$ & $0.183^{* * *}$ & $0.185^{* *}$ & $0.119^{* * *}$ & \\
\hline Importance & $0.904^{* * *}$ & $0.759^{* * *}$ & $0.772^{* * *}$ & $0.522^{* * *}$ & 4.279 & $0.728^{* * *}$ & \\
\hline Distance to coral reef & 0.0383 & & & & & & \\
\hline Distance to seaweed bed & & -0.0371 & & & & & \\
\hline Distance to tidal flat & & & 0.0493 & & & & \\
\hline Distance to sand beach & & & & 0.00678 & & & \\
\hline Distance to mangrove forest & & & & & -0.442 & & \\
\hline
\end{tabular}


Table 3 (continued)

\begin{tabular}{|c|c|c|c|c|c|c|c|}
\hline Variable & Coral reef & Seaweed bed & Tidal flat & Sand beach & Mangrove & Fishing ground & Whole nature \\
\hline Distance to coastal line & -0.00320 & & -0.00995 & & 0.112 & 0.0500 & \\
\hline \multicolumn{8}{|l|}{ Hokkaido area (baseline) } \\
\hline Tohoku area & -0.141 & -0.170 & 0.0441 & -0.103 & -0.158 & -0.277 & 3.633 \\
\hline Kanto area & -0.0259 & -0.189 & -0.109 & $-0.191^{*}$ & -0.379 & $-0.371^{* *}$ & -0.192 \\
\hline Chubu area & -0.124 & -0.177 & -0.0945 & -0.0752 & -0.302 & -0.166 & 0.195 \\
\hline Kinki area & -0.0924 & $-0.312^{* *}$ & -0.231 & $-0.264^{* *}$ & $-0.674^{*}$ & $-0.463^{* * *}$ & -0.268 \\
\hline Chugoku area & -0.115 & $-0.242^{*}$ & -0.0608 & -0.168 & $-0.859^{* *}$ & $-0.330^{*}$ & -0.418 \\
\hline Shikoku area & -0.200 & -0.237 & -0.0145 & -0.0549 & $-0.884^{*}$ & $-0.450^{* *}$ & -0.279 \\
\hline Kyushu/Okinawa area & 0.0288 & -0.0216 & 0.140 & 0.0141 & -0.475 & 0.0320 & -0.147 \\
\hline CBI score 4 & $-0.00529^{*}$ & 0.00174 & 0.00190 & 0.00155 & -0.00831 & 0.00450 & 0.00326 \\
\hline CBI score 6 & 0.00385 & -0.00101 & -0.000177 & -0.000694 & 0.00903 & 0.00339 & -0.00618 \\
\hline CBI score 7 & -0.000947 & -0.00391 & -0.00260 & -0.00209 & -0.00132 & -0.00848 & -0.00765 \\
\hline Constant & 0.312 & $0.868^{* * *}$ & 0.389 & 0.423 & $3.758^{*}$ & $0.820^{* *}$ & $2.125^{* * *}$ \\
\hline Observations & 3092 & 3084 & 3084 & 3089 & 3086 & 3087 & 3145 \\
\hline
\end{tabular}

The distance to coastal line is excluded from the equation of seaweed bed and sand beach because it is strongly correlated with the distance to seaweed bed and the distance to sand beach

**** $p<0.01,{ }^{* *} p<0.05, \stackrel{*}{p} p<0.1$

which indicates that the respondents living in the baseline area, i.e., Hokkaido, are more likely to be WTP to maintain natural capital than the residents in other areas. In terms of the CBI score, score 6 has a positive correlation with the probability of paying for agricultural lands, which indicates that, if a local government actively considers biodiversity conservation in their city planning, the residents of the municipality are more likely to pay to maintain agricultural land. In contrast, score 7 has a negative correlation with the probability of paying to maintain agricultural lands and forests, indicating that, if the local government encourages the residents and organizations in the municipality to join their activities related to biodiversity conservation, the residents are more likely to state zero WTPs for agricultural lands and forests.

The coefficient estimates in the outcome equation reveal that the variables of gender, graduate, household size, household income, visit frequency, perceived importance, and area of residence can be the determinants for the WTP amounts to maintain much of the natural capital. Household income and visit frequency positively influenced the all WTP amounts at the $1 \%$ significance level. Male and graduated respondents tended to state a higher WTP for many natural capital categories than females. Perceived importance also positively affected the WTP amounts for some natural capital. Only orchards and pastures were not influenced by perceived importance in terms of both the probability of paying for them and the WTP amounts. Household size negatively affected the WTP values for many of the natural capital categories. All of the estimated coefficients for the regional dummies were negative; many were statistically significant, which indicates that the WTP to maintain natural capital is higher among residents in the Hokkaido region compared with the other regions. In addition, the distance from the coast had a negative effects on the WTP to maintain seaside protection forests, tidal flats, mangrove forests, and fishing grounds. This implies that people living near the coast tended to state a higher WTP for these natural capital categories.

There are some differences between natural capital in which covariates may affect the WTP for each. For example, while the WTP amount for natural forests, coral reefs, seaweed beds, tidal flats, mangrove forests, and fishing grounds is higher among university graduates, other natural capital categories may not be related to educational background. There is a likelihood that higher education allows people to understand the importance of natural capital that has mainly indirect use value and non-use value with respect to their ecosystem services compared with agricultural lands and plantation forests that have a large direct use value. In addition, the WTP for coral reefs, seaweed beds, and mangrove forests were higher if the respondents had children while the other natural capital categories were not related to having children. One possible reason for the relationship between having children and a higher WTP for a certain natural capital is that children receive some environmental education on these natural capital categories. The parent may be affected by their children through their daily conversation in terms of their perceived values of nature. 
Table 4 Mean WTP estimates for maintaining the hypothesized amount of each $\mathrm{NC}$

\begin{tabular}{llccl}
\hline & \multirow{2}{*}{$\begin{array}{l}\text { Hypothesized } \\
\text { amount of decrease }\end{array}$} & \multicolumn{2}{l}{ Mean WTP $(2019$ US\$/household/year $)$} \\
\cline { 3 - 5 } & & & Kristrom mean & $\begin{array}{l}\text { Unit Kristrom mean } \\
\left(10^{-3} \text { per ha or } 10^{-3}\right.\end{array}$ \\
& & & & per t $)$ \\
\hline Paddy & 12,500 ha & $11.0(9.8-12.2)$ & $11.8(10.5-13.0)$ & 0.941 \\
Crop & 7,500 ha & $10.8(9.6-12.0)$ & $11.6(10.3-12.9)$ & 1.546 \\
Orchard & 5,000 ha & $9.5(8.4-10.6)$ & $10.3(9.2-11.5)$ & 2.063 \\
Pasture & 2,500 ha & $9.0(7.9-10.0)$ & $9.8(8.7-10.9)$ & 3.922 \\
Plantation forest & 18,000 ha & $9.2(8.2-10.3)$ & $10.1(8.9-11.2)$ & 0.559 \\
Natural forest & 10,000 ha & $10.7(9.5-11.8)$ & $11.6(10.4-12.8)$ & 1.163 \\
Seaside forest & 22 ha & $10.1(9.0-11.2)$ & $11.0(9.8-12.2)$ & 499.296 \\
Coral reef & 70 ha & $9.8(8.7-10.9)$ & $10.7(9.5-11.8)$ & 152.361 \\
Seaweed bed & 2,000 ha & $8.5(7.5-9.5)$ & $9.3(8.2-10.4)$ & 4.658 \\
Tidal flat & 99 ha & $8.3(7.3-9.3)$ & $9.2(8.1-10.2)$ & 92.621 \\
Sand beach & 56 ha & $8.9(7.9-10.0)$ & $9.8(8.7-10.9)$ & 175.565 \\
Mangrove & 1.5 ha & $9.0(7.9-10.0)$ & $9.8(8.7-11.0)$ & 6562.749 \\
Fishing ground & $178,000 \mathrm{t}$ & $9.6(8.5-10.7)$ & $10.5(9.3-11.6)$ & 0.059 \\
Whole nature & - & $34.9(32.7-37.1)$ & $40.4(36.0-44.8)$ & - \\
\hline
\end{tabular}

The values in parentheses are 95\% confidence intervals based on Blaine et al. (2005) and Vaughan and Rodriguez (2001)

\section{Mean WTP estimation}

Table 4 lists the mean WTP estimates of natural capital. In general, the Kristrom mean estimates are slightly higher than the Turnbull LBM. The rightmost column in Table 4 shows the unit WTP per hectare or ton. The unit WTP is substantially affected by the hypothesized decreasing amount. The hypothesized decreasing amounts were assumed to be higher if the total amount of the corresponding natural capital was larger. From these perspectives, the estimated unit WTPs are higher among the natural capital categories with small total amounts. Besides that, there are some unique findings from the results of the mean WTP estimates. For example, even though the hypothesized decreasing amount of natural forests is smaller than that of plantation forests, the WTP to prevent a decrease by the hypothesized amount is higher among natural forests than plantation forests. In addition, considering the rate of decline, seaweed beds have a lower WTP compared with other marine natural capital.

\section{Natural capital prediction and its importance to sustainability}

\section{Scenarios and methodology}

We conducted a future prediction of the amount of natural capital in 2050 at the municipality level. The scenario prediction of natural capital makes it possible to evaluate which pathways will lead to a more sustainable future.
For our prediction, we applied the scenarios developed by the Predicting and Assessing Natural Capital and Ecosystem Services (PANCES), which is a 5-year research project with the goal of developing national scale future scenarios mainly to assess future changes in natural capital and ecosystem services (Saito et al. 2019). The scenarios diverge depending on two drivers: investments in infrastructure and population. While infrastructure development and disaster management can be conducted on an ecosystem basis (e.g., the use of green infrastructure and renewable energy) or man-made basis (e.g., the use of conventional infrastructure, optimization of conventional power generation), population is likely to be either concentrated in urban areas or dispersed throughout rural areas. Different combinations of these two factors produce the following four scenarios, in addition to a business-as-usual (BAU) scenario: a natural capital-based compact society (NC), a natural capital-based dispersed society (ND), a produced capital-based compact society (PC), and a produced capital-based dispersed society (PD). The PANCES project has already made predictions of the population distribution and land use changes by 2050 for each scenario (Hori et al. 2020a, b; Shoyama et al. 2019).

We used these data for population and land use prediction as input values for our natural capital prediction. The land use prediction data were constructed as a thematic map on a $1 \mathrm{~km}$ grid level (Shoyama et al. 2019). Each cell is categorized into any of the following: (1) residential area, (2) paddy field, (3) cropland, (4) other agricultural land, (5) abandoned farmland, (6) grassland and bush, (7) natural forest, (8) secondary forest, (9) plantation forest, and (10) 
others. We used the number of cells categorized as paddy field, cropland, other agricultural land (including orchard and pasture), plantation forest, natural forest, and secondary forest within each region at the municipality level to predict the natural capital area in 2050 for each scenario. The population projection data describe the Japanese population distribution in 2050 at a $500 \mathrm{~m}$ grid level on the condition that Japanese society will follow any of the scenarios of population dispersion: extreme case compact society, middle case compact society, extreme case dispersed society, middle case dispersed society, or business as usual (Hori et al. $2020 \mathrm{a}, \mathrm{b})$. Using these data, we estimated the household number of each municipality in 2050 , which is necessary to calculate the shadow price of each natural capital for each scenario. We assumed that the NC and PC scenarios promote an extreme case compact society while the ND and PD scenarios lead to an extreme case dispersed society in terms of the population distribution.

The WTP values estimated from our survey data were the amounts of money that households can pay annually for the next 10 years from 2020 to maintain natural capital. To calculate the total amount of natural capital in monetary value, we calculated the shadow price per hectare based on the annual WTP per household. First, we obtained the number of households in 2050 for each scenario and each region, as follows: our sample into eight regions in Japan and categorizing each municipality into urban or rural areas (e.g., Hokkaido urban, Hokkaido rural, and Tohoku urban). Then, Kristrom's mean WTPs were estimated among the 16 subsamples. Finally, one of the 16 types of WTP values was assigned to each corresponding municipality.

The GDP prediction data was derived from the Shared Socioeconomic Pathways (SSP) 2 from Riahi et al. (2017), which assumes that GDP in Japan will maintain a low growth rate until 2050. This GDP scenario is suitable for PANCES scenarios because PANCES assumes low economic growth in Japan toward 2050 among all their scenarios. We use $5 \%$ as a discount rate, $\delta$, to obtain the discounted present values for each natural capital stock in the same manner as Ikeda and Managi (2019) and UNU IHDP and UNEP (2014). Finally, the shadow price can be calculated as the sum of the discounted present value in year $t$.

To obtain the total amount of each natural capital $i$ in municipality $r$ for scenario $s$, we calculated the total hectare of each natural capital in each municipality using the land use prediction data. The data for land use are from Shoyama et al. (2019), which were formed as a thematic map at the $1 \mathrm{~km}$ grid level. In this data, there is no information on the hectare value of each natural capital within a grid. For example, if natural forest occupies the largest area within a grid, it is categorized as a natural forest grid even if there is also a smaller area of plantation forest

Number of households $\mathrm{sr}_{\mathrm{r}}=$ Population $_{\mathrm{sr}} \times\left(\frac{\text { Number of households }_{2015, \mathrm{r}}}{\text { Population }_{2015, \mathrm{r}}}\right)$,

where $s$ refers to the 5 scenarios $(=\mathrm{BAU}, \mathrm{NC}, \mathrm{ND}, \mathrm{PC}$, or PD) and $r$ refers to the municipality (1,880 available observations). The source of the population data was the PANCES population projection data (Hori et al. 2020a, b). We assumed that the ratio of number of households to population in each municipality will not change from 2015 to 2050.

Next, we calculated the shadow price of each natural capital with reference to Managi and Kumar (2018) and UNU IHDP and UNEP (2014) as follows: or agricultural land within this grid. Therefore, we first need to estimate the hectare value of natural capital $i$ within each grid categorized as natural capital $i$, as follows:

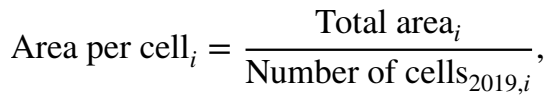

where Area per cell ${ }_{i}$ is the area of natural capital $i$ per cell, Total area is the current area size of each natural capital (the values are shown in Fig. 12), number of cells ${ }_{2019}$, and $i$ is the number of land use cells corresponding to natural capital $i$

$\mathrm{SP}_{\mathrm{isr}}=\sum_{t=1}^{\infty}\left\{\mathrm{WTP}_{2019, \mathrm{ir}} \times \frac{\mathrm{GDP}_{2050}}{\mathrm{GDP}_{2019}} \times\right.$ Number of households $\left._{\mathrm{sr}} \times \frac{1}{(1+\delta)^{t}}\right\}$,

where $\mathrm{SP}_{\text {isr }}$ is the shadow price of natural capital $i$ for scenario $s$ and municipality $r$, defined as the 2019 US\$ per hectare value, and $\mathrm{WTP}_{2019 \text {,ir }}$ is the mean WTP to prevent natural capital $i$ from decreasing one hectare among the people living in municipality $r$. For the WTP value, we calculated the Kristrom mean value (Eq. (5)) under the assumption that the mean WTP is different by region and type of municipality (urban or rural). We created 16 subsamples by dividing in Japan. As 2019 values are not available from the land use prediction data, we assumed that the land use situation in 2019 was the same as that in the 2020 BAU scenario. Then, we obtained the total area of natural capital $i$ in municipality $r$ in 2050 for scenario $s$ ( Area $\left._{\text {iss }}\right)$ as follows:

Area $_{\text {isr }}=$ Number of cells $\mathrm{isr}_{\text {sr }} \times$ Area per cell $_{\mathrm{i}}$. 


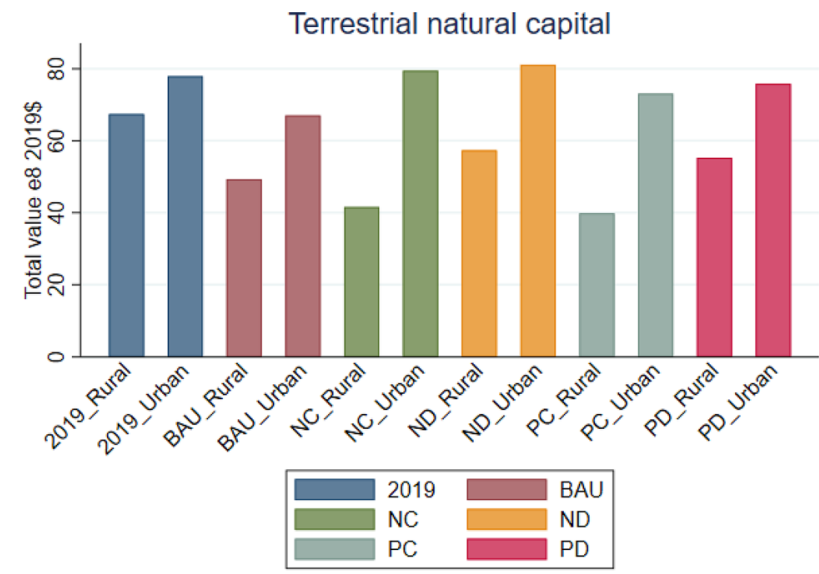

Fig. 3 Scenario prediction of terrestrial natural capital in 2019 US\$

Finally, we obtained the total amount of natural capital $i$ in municipality $r$ for scenario $s$ in monetary terms using the following equation:

Natural capital $_{\text {isr }}=\mathrm{SP}_{\text {isr }} \times$ Area $_{\text {isr }}$.

The unit of $\mathrm{SP}_{\mathrm{isr}}$ is the 2019 US\$ per hectare and the unit of Area $_{\text {isr }}$ is hectare. Therefore, the unit of Natural Capital is the 2019 US\$. We calculated the total amount of terrestrial natural capital in municipality $r$ for scenario $s$ by summing the amount of all of the natural capital in each municipality as follows:

Terrestrial natural capital $_{\mathrm{sr}}=\sum_{i}$ Natural capital $_{\text {isr }}$,

where $i$ includes five types of natural capital: paddy fields, crop fields, other agricultural lands, plantation forests, and natural forests.

\section{Prediction results}

Figure 3 shows the results of the terrestrial natural capital prediction. The bar chart shows the total value of terrestrial natural capital for each scenario in rural and urban areas. Whichever pathways Japanese society will follow, the total value of terrestrial natural capital in rural areas will decrease from 2019 to 2050 . In urban areas, only the natural capitalbased society will enhance the value of terrestrial natural capital.

Figure 3 indicates that rural areas are likely to be affected by whether Japan will follow a compact or dispersed scenario while urban areas appear to be influenced by whether the scenario is natural capital-based or produced capitalbased. The population in rural areas becomes higher with the promotion of a dispersed society, which leads more people to invest in the natural capital of rural areas. In addition, the

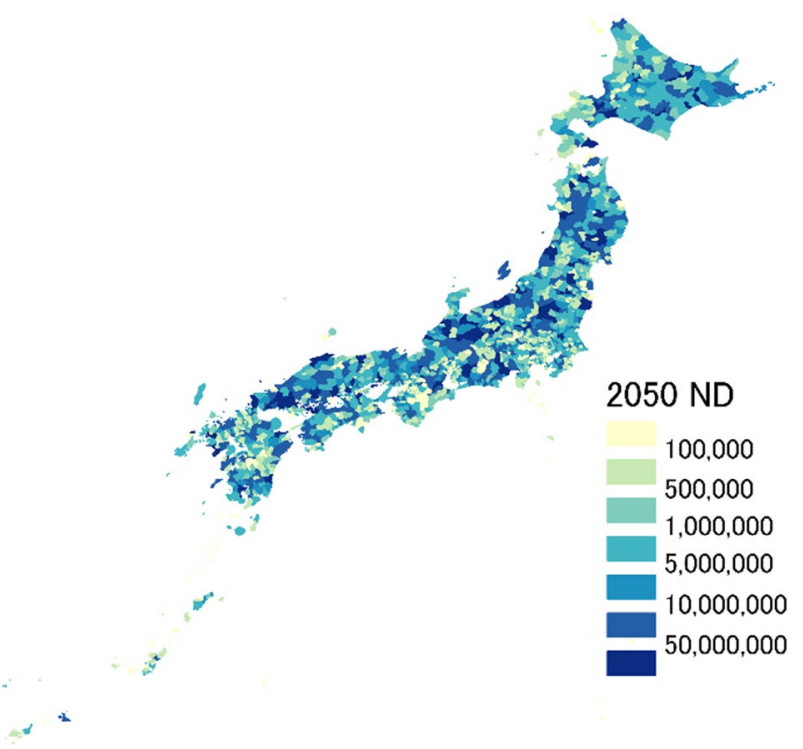

Fig. 4 The distribution of terrestrial natural capital in 2019 US\$ for ND scenario

natural capital-based society will maintain more agricultural lands and forests in urban areas, leading to a higher value of natural capital. Consequently, the natural capital-based dispersed (ND) society will sustain the highest total value of terrestrial natural capital among all scenarios.

Figure 4 shows the distribution of terrestrial natural capital with the promotion of the ND society. This indicates that the ND scenario leads many municipalities in Japan to maintain moderate to large values of terrestrial natural capital. Figure 13 in the Appendix shows maps of the distribution of terrestrial natural capital for all scenarios. These maps show that more municipalities sustain terrestrial natural capital in dispersed societies than in compact societies. Figure 13 in Appendix shows the predicted value of each natural capital.

\section{Converting abandoned agricultural lands into forests}

As the number of farmers is decreasing due to population decline, aging, and social changes, abandoned agricultural land is increasing, especially in rural areas. According to MAFF (2020), abandoned agricultural land increased from 244,000 ha in 1995 to 423,000 ha in 2015. In such a situation, the abandonment of agricultural land and its impact on biodiversity have attracted the attention of researchers and practitioners. Some studies have argued that the abandonment of farmland is one of the factors that causes the loss of biodiversity and ecosystem services (Kleijn and Báldi 2005; Osawa et al. 2013; Tsunoda and Enari 2020). Under these circumstances, many studies have argued the effectiveness 
(1) Plantation forests

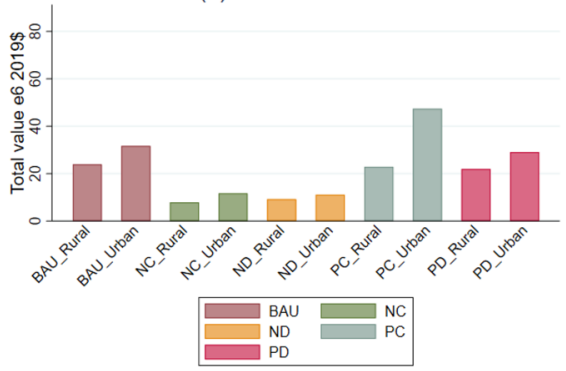

(1) Plantation forests

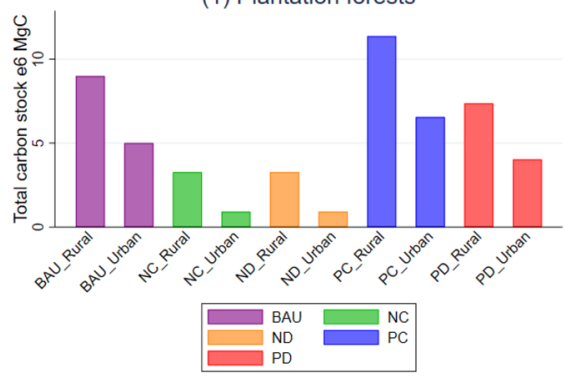

(2) Secondary forests

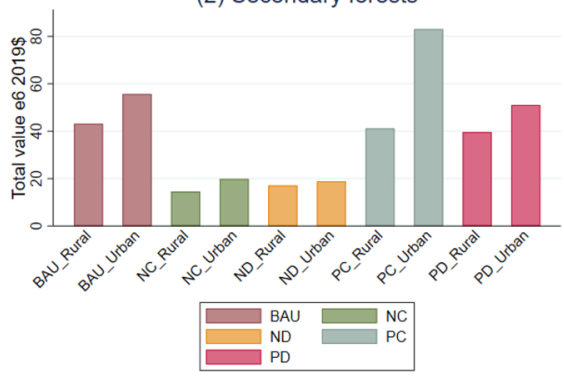

(2) Secondary forests

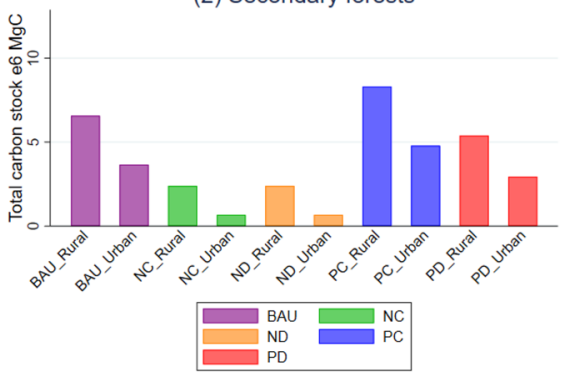

(3) Plantation and secondary forests

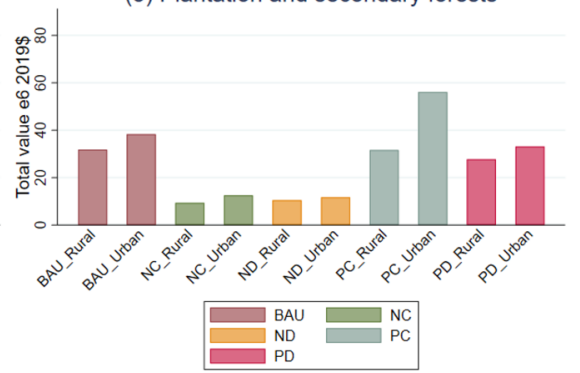

(3) Plantation and secondary forests

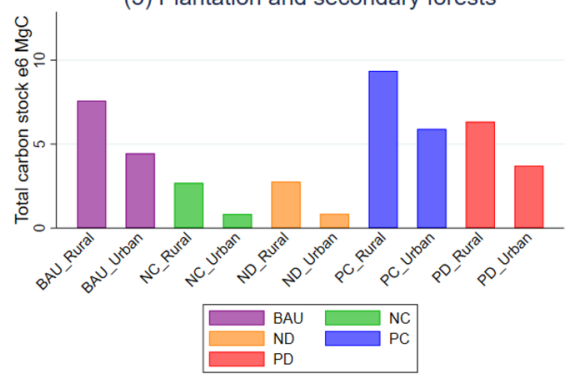

Fig. 5 Increases in natural capital values (above) and carbon stocks (below) by conversion of abandoned agricultural lands into forests

of converting abandoned agricultural land into forests by active afforestation or rewilding (MacDonald et al. 2000; Navarro and Pereira 2012; Tsunoda and Enari 2020). The conversion of abandoned land into forest should have a significant potential to recover functions, such as protecting soil and water resources and enhancing biodiversity. Therefore, analyzing how much benefit can be expected when abandoned agricultural land in Japan is converted to forests from ecosystem services, natural capital stock, and national land conservation perspectives is worthwhile.

This subsection reveals the future of natural capital stock in Japan if abandoned agricultural land is converted to forests during the period between 2030 and 2050. We calculated the increase in the monetary value of natural capital stock generated by the conversion of abandoned agricultural land into forests, considering five scenarios developed by PANCES.

First, using the land use prediction map from Shoyama et al. (2019), we detected all cells that are categorized as abandoned farmland as of 2030 for each PANCES scenario (BAU, NC, ND, PC, and PD). Shoyama et al. (2019) assumed that, in the BAU scenario, cultivated area will continue to decrease, which causes an increase in abandoned farmland. The natural capital-based scenario intervenes by managing unused land, converting abandoned agricultural land into cropland, other agricultural land, and secondary forest. In contrast, the produced capital-based scenario does not conduct such management for unused land. Therefore, a larger area of abandoned agricultural land will remain in the produced capital-based scenario than in the natural capitalbased scenario. In addition, agricultural land and plantation forests are maintained more in the dispersed society, which indicates that there will be a smaller area of abandoned agricultural land in the dispersed scenario than in the compact scenario.

Next, we developed scenarios for the conversion of abandoned agricultural lands into forests. Three scenarios were constructed depending on the balance between plantation forests and secondary forests: (1) all into plantation forests, (2) all into secondary forests, and (3) into plantation and secondary forests. In scenario (1), all detected cells categorized as abandoned farmland as of 2030 will be converted into plantation forests by 2050 . In contrast, all abandoned farmland will be converted into secondary forests in scenario (2). Scenario (3) assumes that, if the population within a circle with a radius of $5.5 \mathrm{~km}$ around an abandoned agricultural land is over 500, the abandoned land becomes a plantation forest and, if under 500, the abandoned land becomes a secondary forest. Under this assumption, approximately half of abandoned agricultural lands in Japan become plantation forests while the other half becomes secondary forests.

Then, we calculated the increase in monetary value of terrestrial natural capital by converting abandoned agricultural lands into forests for each of the five PANCES scenarios and the three conversion scenarios developed above. We first obtained the areas of plantation forest generated by the conversion in each municipality by multiplying the number of cells converted into plantation forests in each municipality by the hectare value of each cell of plantation forest calculated in Eq. (8). This same method was applied to secondary forests to obtain the areas of secondary forest generated. We then multiplied the shadow prices of plantation forest and natural 
forest estimated in Eq. (7) by the generated areas of plantation forest and natural forest, respectively. Finally, we estimated the increases in the monetary value of natural capital for each scenario by converting abandoned land into forest.

Figure 5 shows the results of the estimated values of the increases in terrestrial natural capital via the conversion of abandoned agricultural lands into forests. The values were summed within rural and urban areas. We found that the secondary forest-only scenario yielded the highest increase in terrestrial natural capital. The main reason is that the WTP to maintain 1 ha of natural forest is approximately twice as high as 1 ha of plantation forest (see Table 4), which leads to a higher shadow price for secondary forests. In terms of the differences between the PANCES scenarios, the values of the increases in terrestrial natural capital are higher in the produced capitalbased scenarios compared with the natural capital-based scenarios because a larger area of abandoned agricultural lands remains in the produced capital-based society in Japan. This implies that there is a greater potential for enhancing natural capital via the conversion of abandoned agricultural land into forest in a produced capital-based society than in a natural capital-based society. In particular, the produced capital-based compact society has the greatest potential to enhance natural capital from abandoned agricultural lands in urban areas.

We found that the maximum value of the increase in natural capital via the conversion corresponds to approximately $1 \%$ of the total value of terrestrial natural capital in Japan (Fig. 3). This maximum increase can be realized when Japanese society follows a produced capital-based compact society and all abandoned agricultural lands will be converted into secondary forests from 2030 to 2050 (1.04\% increase in rural areas and $1.14 \%$ in urban areas). In contrast, when Japanese society follows a natural capital-based society, increases in natural capital via the conversion of abandoned agricultural land into secondary forests becomes approximately $0.2-0.3 \%$ of the total value of terrestrial natural capital in Japan.

In addition, we calculated the increase in the carbon stock from the conversion of abandoned agricultural lands into forests. By increasing the amount of carbon stock in forests, $\mathrm{CO}_{2}$ can be reduced and the impacts from climate change may be mitigated. Therefore, the conversion of abandoned farmland into forests may contribute to climate change mitigation.

First, we calculated the amount of carbon stock per hectare in the major plantation and secondary forests in Japan. ${ }^{3}$ Our estimation yields $108.896 \mathrm{Mg} \mathrm{C} / \mathrm{ha}$ as the carbon stock of Japanese cedar (Cryptomeria japonica), which occupies

\footnotetext{
3 We adopted the same method used in Egusa et al. (2020) to calculate the amount of carbon stock per hectare. In terms of the parameters required for this calculation, timber volume was extracted from the National Forest Inventory data from the Japan Forestry Agency (http://www.rinya.maff.go.jp/j/keikaku/tayouseichousa/). Other parameters were obtained from the National Institute for Environmental Studies website (http://www-gio.nies.go.jp/aboutghg/nir/2020/ NIR-JPN-2020-v3.0_J_GIOweb.pdf).
}

the largest share (44\%) of plantation forests in Japan (Forestry Agency 2017). In addition, the estimated carbon stock of oak (Quercus), the major natural forest in Japan, is $92.397 \mathrm{Mg} \mathrm{C} / \mathrm{ha}$. We applied these estimated values for Japanese cedar and oak to the carbon stock of plantation forests and secondary forests, respectively.

Then, we estimated an increase in the total carbon stock via the conversion of abandoned farmlands into forests for each scenario. The increase in the carbon stock was calculated by multiplying the values of the carbon stock per hectare by the areas of forests gained from the conversion of abandoned farmlands.

The lower charts in Fig. 5 describe the estimated increase in carbon stock for each scenario. Unlike the monetary values, the increase in carbon stock becomes the largest in the plantation forest-only scenario. In addition, rural areas can acquire a larger increase in their carbon stock from the conversion of abandoned farmlands than urban areas. In terms of the PANCES scenarios, the PC pathway can realize the largest growth in the carbon stock because of the largest total area of abandoned farmlands.

\section{Ecological footprint prediction}

This subsection focuses on what happens to the environmental burden caused by human activities at the municipality level in the future. To calculate the future environmental burden, the ecological footprint is a useful index. The concept of the ecological footprint is widely recognized as one of the measures of environmental burden since it was first proposed nearly 30 years ago (Rees 1992).

Hori, Shirahama, et al. (2020b) estimated the environmental burden at the grid level in Japan as of 2011 using the ecological footprint index. Using data on the ecological footprint and PANCES population data (Hori et al. 2020a), we predicted the future environmental burden at the municipality level by 2050 if the Japanese population distribution conforms to any of the following scenarios: extreme compact society (Com), extreme dispersed society (Dis), or business as usual (BAU). The prediction equation is as follows:

$\mathrm{EF}_{\mathrm{sr}}=\mathrm{EF}$ per person ${ }_{2011, \mathrm{r}} \times$ Population $_{\mathrm{sr}}$,

where $\mathrm{EF}_{\mathrm{sr}}$ is the total value of the ecological footprint in municipality $r$ for scenario $s$ (gha) and EF per person 2011 , and ${ }_{r}$ is the average ecological footprint per person in municipality $r$ in 2011 (gha/person). Hori et al. (2020a, b) assumed that the amount of consumption of various goods differs by municipality. Therefore, the ecological footprint per person is also different at the municipality level. The value of Population ${ }_{\mathrm{sr}}$ was obtained from the data reported in Hori et al. (2020a). Equation (12) assumes that only the change in population in the area induces the change in the 

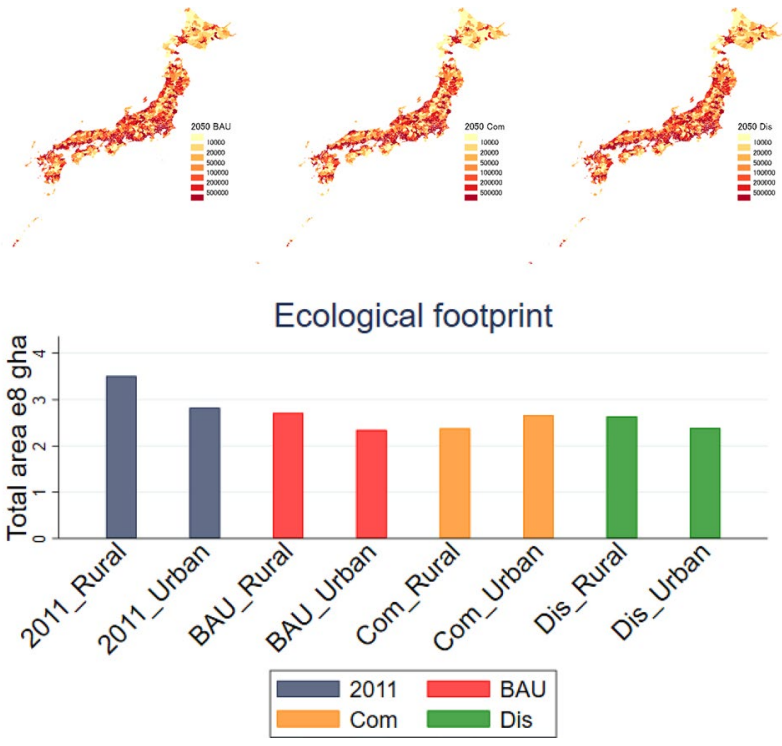

Fig. 6 Scenario prediction of ecological footprint (gha). The thresholds of color classification of the maps are based on seven quantiles for 2011 values

ecological footprint in each municipality. We also assumed that the ecological footprint per person in each municipality will be constant from 2011 to 2050.

Figure 6 shows the results of the ecological footprint prediction. The bar chart at the bottom displays the total gha values of the ecological footprint in rural and urban areas in 2011 and 2050 with the three scenarios.

Irrespective of the scenario that the Japanese population will conform to, the total value of the ecological footprint will decrease from 2011 to 2050 because the total population in Japan will decrease by 2050 . This declining trend is notable, especially in rural areas. Different pathways produce a variation in the total value of the ecological footprint between rural and urban areas. In rural areas, the ecological footprint becomes higher with the promotion of the BAU or dispersed scenario, whereas the ecological footprint in urban areas will be higher with a compact society. Compared with a compact society, a dispersed society induces a moderate to large value for the ecological footprint in a larger number of municipalities.

\section{Eelgrass and seaweed bed prediction}

In addition to the terrestrial natural capital, we predict the future of some coastal natural capital using the PANCES scenarios. We focused on area changes of eelgrass beds and seaweed beds, which are the main ecosystems of the sea distributed on the coasts around Japan.

We used the data of the distribution of eelgrass and seaweed beds collected at $10 \mathrm{~km}$ grid level by the Ministry of the Environment (1994). An estimation model was created by a machine learning by the gradient boosting machine (GBM) for predicting the area of eelgrass beds and seaweed beds. We included latitude, longitude, water temperature, coastline length, chlorophyll a, coastal farmland rate, wave intensity, tide size, coastal population, and predicted water quality (NO3) as explanatory variables. ${ }^{4}$ Among them, water quality was estimated using H2O's GBM on R with driver variables including the population, land use, topography, and meteorological conditions. When interpolating the water quality value to seaside, we used a predicted value if the predicted value exists within the $10 \mathrm{~km}$ grid. If there are multiple predicted values exist, we used the weighted average value based on the product of area size and precipitation. If the value does not exist within the grid, the value of the nearest estuary was used. The contribution rate of each variable on the size of the area of eelgrass beds and seaweed beds in Japan is shown in Fig. 7.

We predicted the area size of eelgrass beds and seaweed beds at $10 \mathrm{~km}$ grid level in 2050 by each PANCES scenario (NC, ND, PC, PD). Figures 8 and 9 shows the predicted distributions of eelgrass beds and seaweed beds for each scenario. In the estimation of area size, water quality, coastal population and coastal farmland rate are varied between scenarios. Only the grids in which eelgrass beds or seaweed beds exist were used to eliminate the bias in the estimates. In addition, there are error values between actual current area sizes and the values of predicted current area sizes from estimation. To correct such biases, we firstly calculated the change rates from the predicted current values to the predicted values for each scenario in 2050 . Then, we multiplied the change rates for each scenario with the actual current values and obtained adjusted version of predicted values of the area size of eelgrass and seaweed beds for each of the scenarios. Therefore, the results reflect the relative difference between scenarios rather than the quantitative change in absolute values.

Table 5 shows the results of the prediction in the hectare values. The $R$-squared for the model of eelgrass beds was 0.28 , and that of seaweed beds was 0.20 . Climate change will decrease the predicted values of eelgrass and seaweed beds for all scenarios. As a whole, we found only small differences in the predicted values between the scenarios compared to the difference by whether climate change will happen or not. In terms of eelgrass beds, natural capital-based scenario can maintain larger area size than produced capital-based scenario. Additionally, population dispersed scenario keeps larger areas than compact scenario. As a result, ND scenario

\footnotetext{
${ }^{4}$ Data source: water temperature from MIROC5 https://journals. ametsoc.org/jcli/article/23/23/6312/32720/Improved-Climate-Simul ation-by-MIROC5-Mean-States; coastline length from MLIT (2014); chlorophyll a from NASA (2018); coastal farmland rate from Shoyama et al. (2019); wave intensity from CERA-20C https://www. ecmwf.int/en/forecasts/datasets/reanalysis-datasets/cera-20c; tide size from Integrated Climate Data Center (ICDC, icdc.cen.uni-hamburg. de) University of Hamburg https://agupubs.onlinelibrary.wiley.com/ doi/full/10.1002/2013JC009766; coastal population from Hori et al. (2020a)
} 
Fig. 7 Contribution rate of each variable on the size of the area of eelgrass beds and seaweed beds

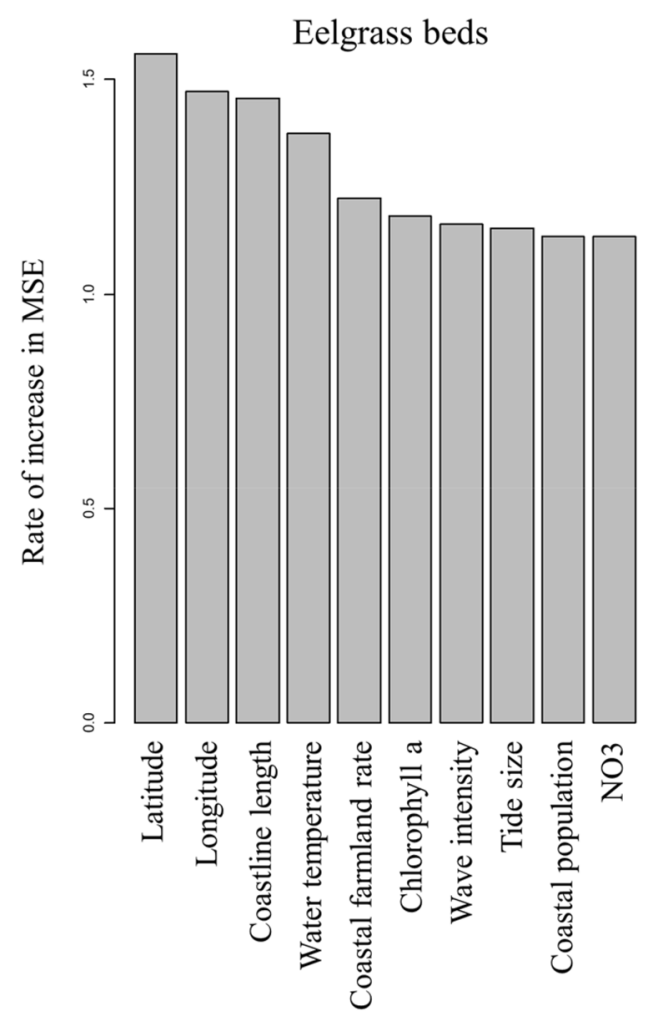

can keep the largest area of eelgrass beds. In terms of seaweed beds, dispersed scenario can maintain larger area size than compact scenario, which is similar to eelgrass beds. However, produced capital-based scenario can keep larger area size than natural capital-based scenario. Thus, PD scenario can keep the largest area of seaweed beds.

Table 6 shows the total values of eelgrass beds and seaweed beds in 2019 US\$ that are calculated using estimated mean WTP (Table 4), hectare values (Table 5) and natural capital approach (described in Eqs. (7) and (10)). We set two scenarios in estimating the shadow prices and total values of eelgrass and seaweed beds. First scenario is total population scenario, in which all people living in Japan are assumed to value all eelgrass beds and seaweed beds existed in Japan. Second scenario is coastal population scenario, in which people living in the municipalities facing the ocean value all eelgrass beds and seaweed beds. As a whole, the relative difference in monetary values between PANCES scenarios are similar to that in the area sizes. Climate change will slightly decrease both the monetary values of eelgrass beds and seaweed beds. It is found that ND pathway maintain the highest values of eelgrass beds and PD maintain the highest values of seaweed beds.

\section{Natural capital for SDGs}

While previous studies have found that natural capital plays an essential role in promoting sustainability and human well-being (Costanza et al. 2017; Díaz et al. 2018), the relationship between natural capital and other issues important to sustainability is still unclear. This subsection reveals the importance of natural capital in terms of achieving SDGs, globally recognized as one of the concrete measures to realize sustainability, as this concept has been proposed within the 2030 Agenda for Sustainable Development of the United Nations Development Programme (UNDP). SDGs consist of 17 goals and 169 targets for poverty and hunger eradication; promotion of peace, justice and human rights; realization of pro-environmental economic growth; and global prosperity (United Nations 2015). There are also 244 indicators to measure the progress of each goal (United Nations 2017).

Previous studies have investigated how the SDG indicators are interconnected with each other. Matsui et al. (2019) conducted a network analysis of the correlations among the Japanese-specific localized version of SDG indicators at the prefectural level. They found that the SDG indicators form a nexus, i.e., a network of connections, correlating with each other, where some indicators (e.g., the average annual value of nitrogen oxides, internet diffusion rate, and proportion of forested land) have relatively strong relations with many other indicators.

If natural capital is essential for sustainability, it also appears to be associated with the SDG indicators. In this subsection, we include natural capital in the nexus of SDG indicators and clarify the interconnectedness between natural capital and SDGs. We used data from Matsui et al. (2019) and incorporated the data on natural capital into the nexus of SDG indicators (May 2018 version). We examined the 


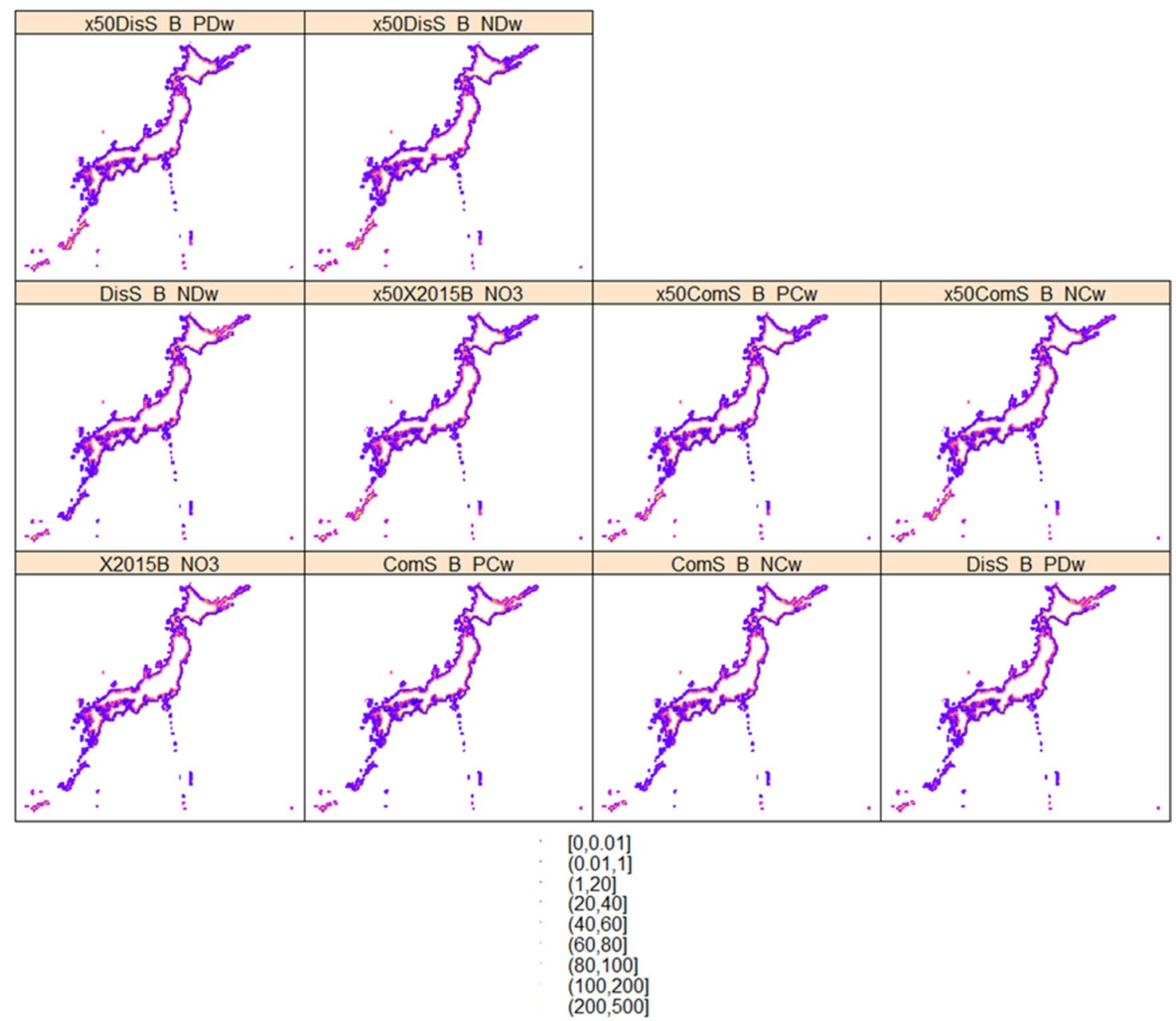

Fig. 8 Predicted distribution of eelgrass beds by scenarios (ha)

correlation of the (1) overall natural capital and (2) WTP for maintaining 13 natural capital types, as well as the overall Japanese environment, with Japanese-specific SDG indicators at the prefectural level. Table 8 in the Appendix ${ }^{5}$ lists the definitions of each SDG indicator. The score of each SDG indicator was standardized as a $z$-value. The sign of the indicator was adjusted to be positive if the indicator shows the higher achievement level of each goal.

First, we analyzed the relationship between natural capital and the inclusive wealth index (IWI) with the SDG indicators. The IWI is another index measuring sustainability that can be calculated at global, national, and regional levels. The IWI consists of produced capital, human capital, and natural capital, where the total wealth can be calculated as the sum of these forms of capital in the inclusive wealth framework (Managi and Kumar 2018; UNU IHDP and UNEP 2014). We used IWI data from Ikeda and Managi (2019), which include

\footnotetext{
${ }^{5}$ For more detailed information on the data for the localized SDGs indicators, see Matsui et al. (2019).
}

produced capital per capita, human capital per capita (education and health), and natural capital per capita at the prefecture level in Japan. Natural capital from their data consists of agricultural land, timber, and non-timber forest.

Figure 10 shows the results of the network analysis. The color and width of each connection between variables describe the sign and strength of the relationship based on Pearson's correlation coefficients. The red color refers to a positive relation while blue refers to negative. The size of each node indicates the strength of the connection with other indices. Natural capital (NatC) is more strongly related to the SDG indicators than artificial capital $(\operatorname{PrdC})$, human capital (HumC), education capital (EduC), health capital (HeaC), and inclusive wealth (IWI). Specifically, natural capital has a negative correlation with index 14.4.1, which refers to the possible magnitude of fishery resources preservation. The negative correlation indicates that prefectures with abundant natural capital have higher rates of catch increase compared with the previous year. Figure 15 
Fig. 9 Predicted distribution of seaweed beds by scenarios (ha)

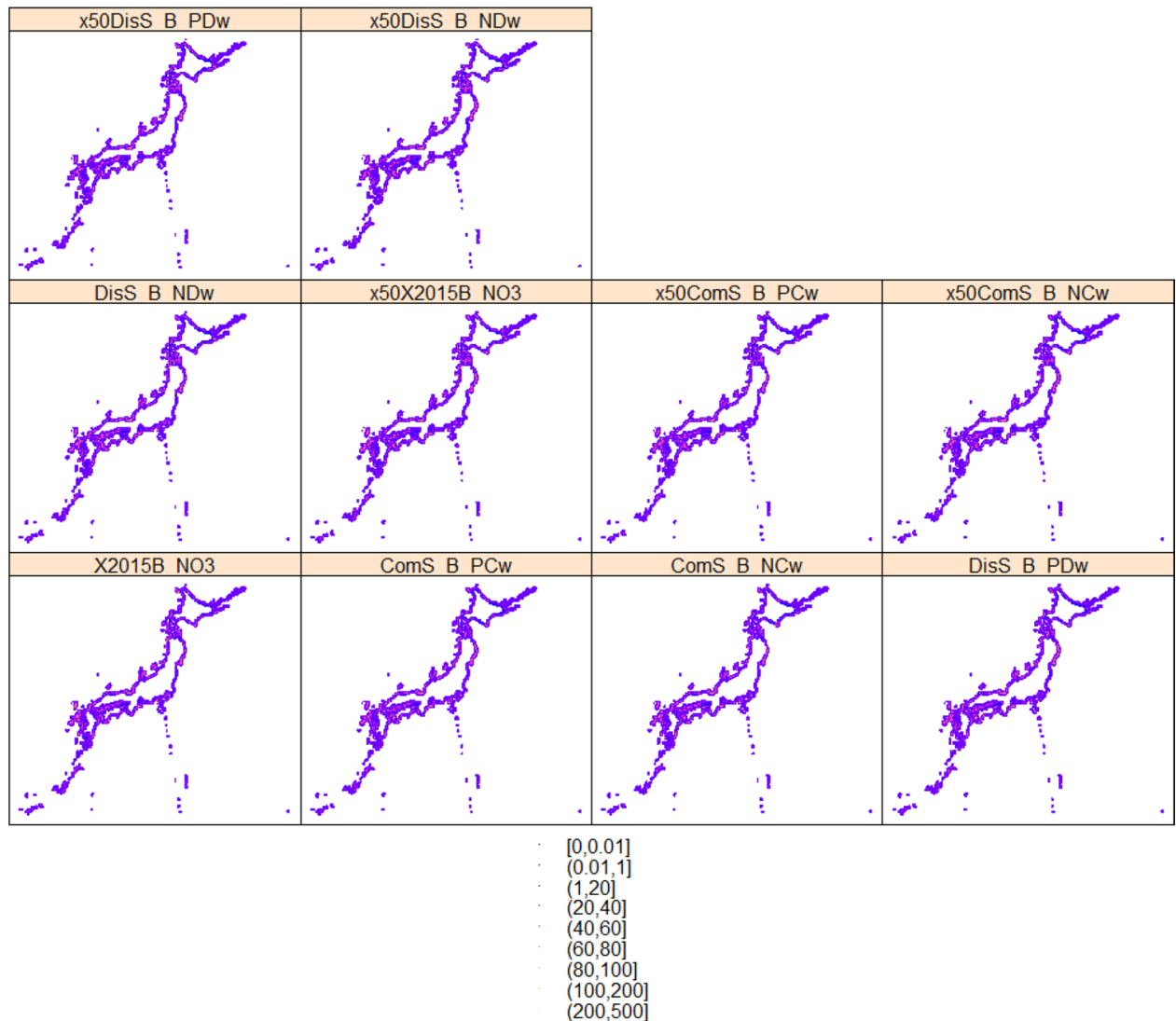

\begin{tabular}{|c|c|c|c|c|c|c|c|c|c|}
\hline Climate Change & 1994 & Predicted & RMSE & MAE & $\mathrm{R}^{2}$ & $\mathrm{NC}$ & ND & $\mathrm{PC}$ & PD \\
\hline \multicolumn{10}{|l|}{ Eelgrass beds (ha) } \\
\hline No & 37,295 & 47,963 & 0.68 & 0.55 & 0.28 & 36,188 & 36,980 & 35,270 & 36,164 \\
\hline Yes & & & & & & 35,966 & 36,745 & 35,001 & 35,888 \\
\hline \multicolumn{10}{|c|}{ Seaweed beds (ha) } \\
\hline No & 138,966 & 50,943 & 0.74 & 0.55 & 0.20 & 136,070 & 138,022 & 137,424 & 139,080 \\
\hline Yes & & & & & & 131,876 & 133,768 & 133,242 & 134,847 \\
\hline
\end{tabular}

\begin{tabular}{llrrrrr}
\hline & Climate change & $2019^{\mathrm{a}}$ & \multicolumn{1}{l}{ NC } & ND & PC & \multicolumn{1}{l}{ PD } \\
\hline Eelgrass beds (total population) & No & 393.450 & 374.307 & 381.625 & 364.811 & 373.199 \\
& Yes & & 372.003 & 379.194 & 362.022 & 370.354 \\
Seaweed beds (total population) & No & 73.729 & 70.780 & 71.632 & 71.485 & 72.181 \\
& Yes & & 68.598 & 69.424 & 69.309 & 69.984 \\
Eelgrass beds (coastal population) & No & 150.715 & 138.060 & 143.552 & 134.557 & 140.382 \\
& Yes & & 137.210 & 142.637 & 133.529 & 139.312 \\
Seaweed beds (coastal population) & No & 28.243 & 26.107 & 26.945 & 26.366 & 27.152 \\
& Yes & & 25.302 & 26.115 & 25.564 & 26.325 \\
\hline
\end{tabular}

${ }^{\text {a }}$ We assumed that the size of the area of eelgrass beds and seaweed beds in 2019 is same as that in 1994
Table 6 Predicted values of eelgrass and seaweed beds in e10 2019US\$
Table 5 Predicted values of the size of the area of eelgrass and seaweed beds the SDG indicators at the prefectural level. The data for the WTP amounts from our survey were used, whose values were averaged by prefecture. Figure 11 shows the results of the network analysis. All WTPs have positive correlations 


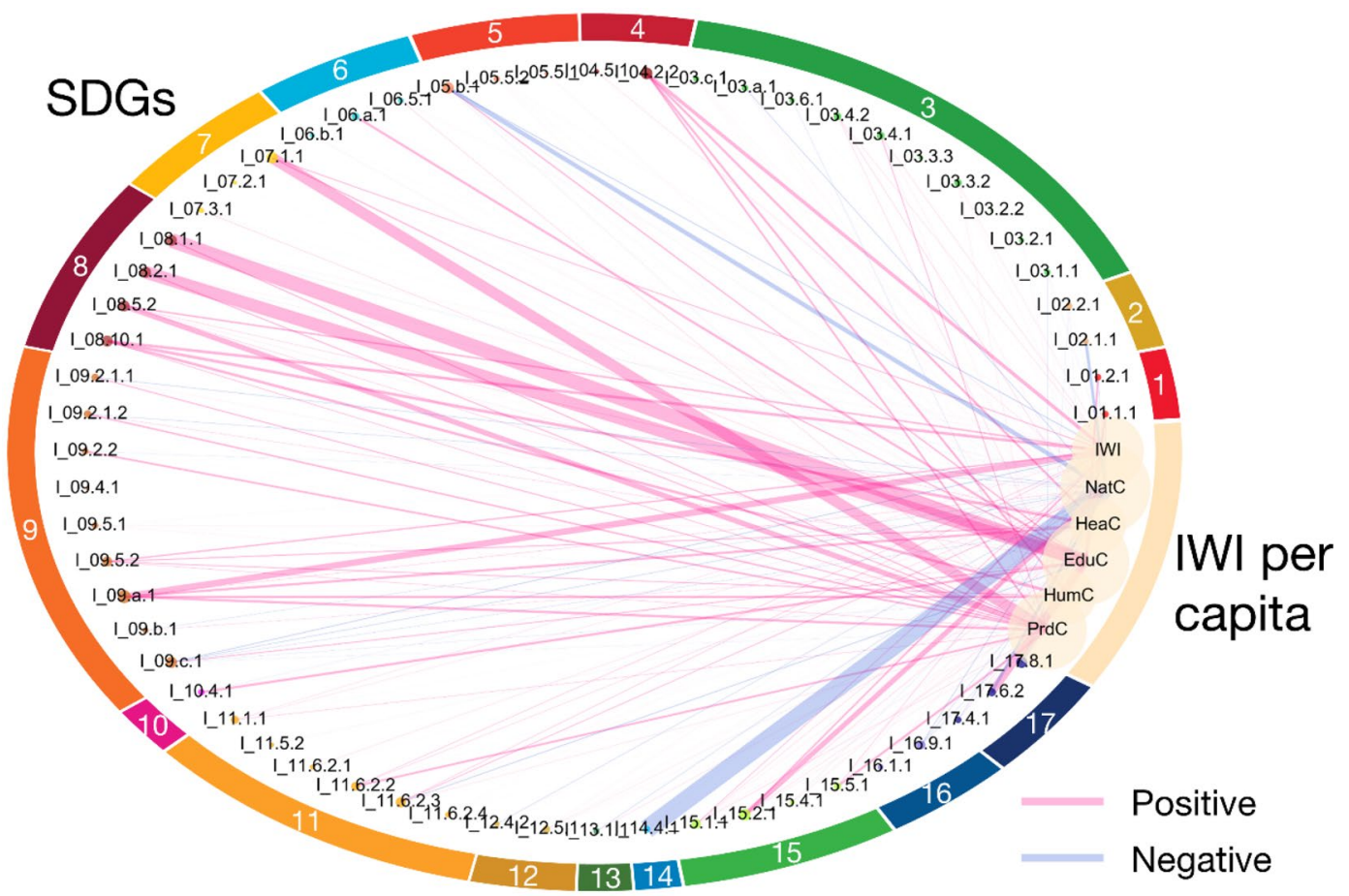

Fig. 10 Network between SDGs indicators and inclusive wealth index (the detail about each goal and indicator is shown in Table 8)

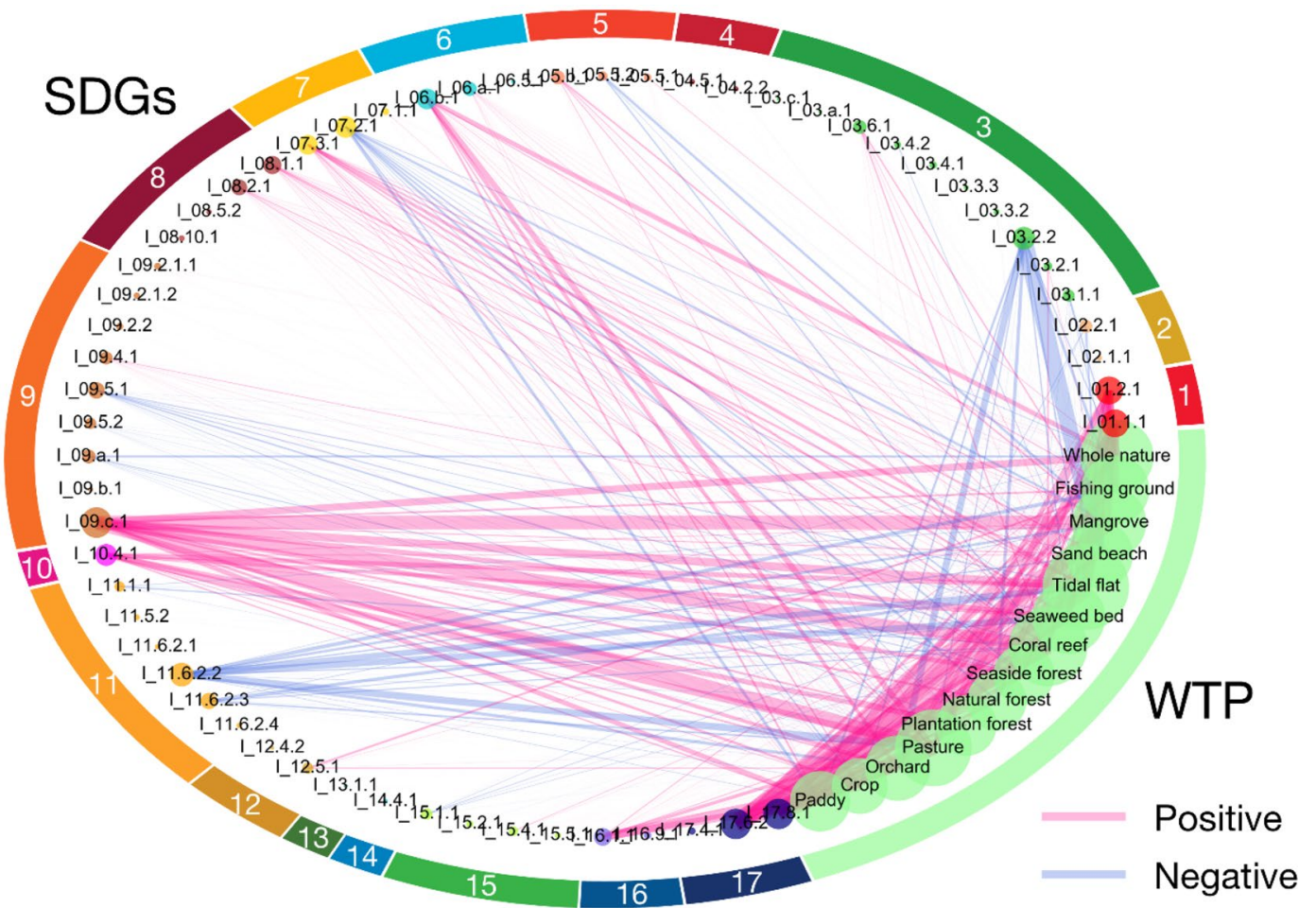

Fig. 11 Network between SDGs indicators and WTPs for maintaining natural capital (the detail about each goal and indicator is shown in Table 8) 
with several SDG indicators, such as 1.1.1 (reducing the relative poverty rate), 9.c.1 (internet usage rate), and 10.4.1 (labor productivity). In contrast, the WTPs have a negative correlation with some SDG indicators, such as 3.2.2 (reducing neonatal mortality), 11. 6.2.2 (reducing the number of days when the photochemical oxidant $(\mathrm{Ox})$ concentration during the day is $0.12 \mathrm{ppm}$ or more), and 11.6.2.3 (reducing the average annual value of $\mathrm{NO}_{\mathrm{x}}$ ). Figure 16 in the Appendix shows the correlation heatmap between these variables.

\section{Discussion}

\section{Insights from the results}

In this study, we used several approaches to investigate the values, determinants, future, and relations for the SDGs of natural capital in Japan. Our ZIOP regression provided several intuitive findings, e.g., household income, visit frequency, and perceived importance positively affect the WTP amount to maintain all or many of the natural capital types. In contrast, some estimated coefficients showed significant effects, whose interpretation should be discussed. Moreover, we revealed the importance of promoting a natural capital-based dispersion scenario to achieve the future sustainability of terrestrial natural capital. In addition, the conversion of abandoned agricultural lands into forests has the potential to achieve a maximum $1 \%$ increase in the value of terrestrial natural capital. The network analysis revealed the interconnectedness between natural capital and SDG indicators at the prefectural level.

Residents in urban areas are less likely to pay for some natural capital than those in rural areas. One of the possible reasons is that urban residents may not feel as though they reap as much of the benefits from natural capital as rural residents who are likely to have spent more time surrounded by nature. This is consistent with evidence from previous studies showing that the less experience an individual has with nature, the lower their attachment to nature and their willingness to conserve nature (Miller 2005; Soga et al. 2016; Zhang et al. 2014). There are also significant regional differences in the WTP for all natural capital types. Specifically, residents in Hokkaido showed both high probability and high WTP amounts for many natural capital types as compared with residents from other regions. Considering that this result was obtained after adjustments for the economic situation and personal attributes, the residents of the Hokkaido region have unique pro-environmental attitudes and awareness of natural capital conservation. The abundant nature in the Hokkaido region may lead to high environmental awareness among the residents. In addition, residents near coasts state higher WTPs for some coastal natural capital. Here, respondents living near the ocean may feel more familiar with coastal natural capital than respondents living far from the ocean.
We also found that the city biodiversity index has effects on the WTP for some natural capital. The coefficient of score 7 indicates that residents are more likely to state a zero WTP for agricultural lands and forests if the local government encourages residents and organizations in the municipality to join their activities related to biodiversity conservation. One of the possible interpretations is that, as the participants of environmental activities have already paid some amount of money and time for these activities, they may believe that they do not need to contribute more money.

In terms of future predictions of terrestrial natural capital, among the PANCES scenarios, the natural capital-based dispersed pathway leads to the highest amount of natural capital in 2050. Therefore, this implies that Japan should follow a natural capital-based dispersed scenario for the sustainable management of natural capital. In contrast, the dispersed scenario will also induce a larger number of municipalities with a high ecological footprint, especially among rural areas. However, the total value of the overall ecological footprint in Japan is not substantially affected by the differences in the scenarios.

In addition, the conversion of abandoned cultivated land into forests leads to an increase in terrestrial natural capital and an increase in the carbon stock in Japan. These results imply that the proper management of abandoned agricultural lands contributes not only to the maintenance of natural capital, but also to the mitigation of climate change in the future.

Moreover, we predicted the future of some marine natural capital. We found that eelgrass beds and seaweed beds can be maintained more up to 2050 if Japan follows the population dispersion scenario compared to compact scenario. It implies that a policy aimed at population dispersion to rural areas can lead to better results in terms of coastal natural capital maintenance in Japan.

Based on the network analysis, natural capital from the inclusive wealth framework has a negative correlation with the conservation of marine resources. This implies the importance of discussing methods to simultaneously conserve agricultural lands, forests, and fisheries resources. The WTPs for agricultural, forest, and marine natural capital are also connected with some SDG indicators. For example, the Internet usage rate has a positive correlation with the WTPs for all natural capital. This implies the likelihood that the Internet plays a role in disseminating knowledge on the importance of natural capital and increasing its valuation. In contrast, the WTP has a negative correlation with the air quality. There is a possibility that a high level of air pollution leads residents to place a higher value on natural capital.

The major limitation of our study is that we were unable to conduct future predictions of marine natural capital because of the limited data availability on marine natural capital that can be used for predictions. Natural marine capital types are intricately intertwined with various elements, such as water temperature, water quality, and fish catches, as compared with 
terrestrial natural capital, which renders future predictions more difficult. Although we estimated the WTPs to maintain a certain amount of marine natural capital, future predictions are a critical topic that should be the focus of future studies.

Another limitation is that the WTP data were collected only from Japanese residents. However, natural capital in Japan can also be valuable to nonresidents. For example, tourists from foreign countries can benefit from the leisure and cultural value of Japanese natural capital. In addition, $\mathrm{CO}_{2}$ absorption by forests can mitigate the impacts of global warming, which should be viewed at a global level. Furthermore, as tidal flats in Japan are the habitats of migratory birds (Iwamatsu et al. 2007), the decline in tidal flats will impact the ecosystems of other countries and regions. For such reasons, focusing only on Japanese residents may yield an underestimation of the value of natural capital. Incorporating such nonresident value into the calculation of natural capital should be another focus of future studies.

\section{Policy implications}

Our natural capital projections show that population concentration in urban areas accelerates the decline in natural capital in local municipalities in rural areas. This can be explained by the decrease in residents who manage natural capital in these areas. More terrestrial and marine natural capital can be maintained by implementing policies aimed at population dispersion and attracting people to rural areas. In addition, converting abandoned farmland into forests in rural areas can yield a potential $0.2-1 \%$ increase in terrestrial natural capital, which can significantly contribute to climate change mitigation by increasing carbon stocks.

Based on these aspects, promoting population dispersion to maintain more natural capital in Japan should be effective. Therefore, we focused on the types of policies that can successfully promote population dispersion. One method is to implement policies aimed at promoting migration. According to Matsushita et al. (2019), elderly people in Japan attach great importance to the natural environment in their surroundings as a factor when selecting their places of residence. This indicates that local governments in rural areas can encourage the migration of elderly by appealing to the abundant natural environment, as well as improving health care and welfare services. The migration of young people is also important for the effective maintenance of natural capital in rural areas. Hori et al. (2020a, b) argue that attractive employment opportunities and livable environments are key to the influx of young people.

However, as the population of Japan is declining overall, a push by all local governments to maintain their population by increasing permanent residents is not pragmatic. Recently, dual residence has attracted the interest of policy makers and has been promoted by the Japanese government (cite MLIT) as one measure to secure human resources to provide manpower for local communities and natural capital management. Specifically, dual residence refers to any lifestyle in which one individual or one household has two (or more) bases of residence. For example, a person who lives in an urban area on weekdays can spend time in a rural area on the weekend. This person can enjoy various benefits from this lifestyle, such as the healing of the body and mind in an environment with abundant nature. Local governments can benefit from such a person in terms of human resources, economic effects, and natural capital management. To more easily disseminate opportunities for dual residence, it is necessary to improve work flexibility by, for example, promoting telework.

Another important measure that can promote population dispersion is introducing better transportation networks. Developing road networks and public transportation sufficient not only to improve the livability of local areas, but also to promote dual residence may be effective. In general, residents in rural areas highly depend on private cars rather than public transportation because of a lack of sufficient public transportation networks (Pucher and Renne 2005). In such a situation, introducing autonomous vehicles may be one solution to improve transport networks in rural areas. Rural residents are more willing to utilize autonomous vehicles than urban residents (Hilgarter and Granig 2020). This implies that the spread of autonomous vehicles has significant potential to promote optimal population distributions for the sustainable management of natural capital in rural areas.

In conclusion, population dispersion is one of the key measures to maintain natural capital, especially in rural areas. To sustainably manage natural capital in Japan, the policies mentioned above should be implemented to maintain the optimal population of municipalities in rural areas. In addition, further analysis is necessary to clarify the effectiveness of policies aimed at migration and dual residence to maintain natural capital.

Acknowledgements This work was supported by the Environment Research and Technology Development Fund (S-15, JPMEERF16S11500), and the Grant in Aid for Japan Society for the Promotion of Science (JSPS) Scientific Research (JP20H00648). Any opinions, findings, and conclusions expressed in this material are those of the authors and do not necessarily reflect the views of the sponsors.

Funding This work was supported by the Environment Research and Technology Development Fund (S-15, JPMEERF16S11500), and the Grant in Aid for Japan Society for the Promotion of Science (JSPS) Scientific Research (JP20H00648).

\section{Appendix}

See Figs.

12, 13, 14, 15, 16 and Tables 7, 8 . 


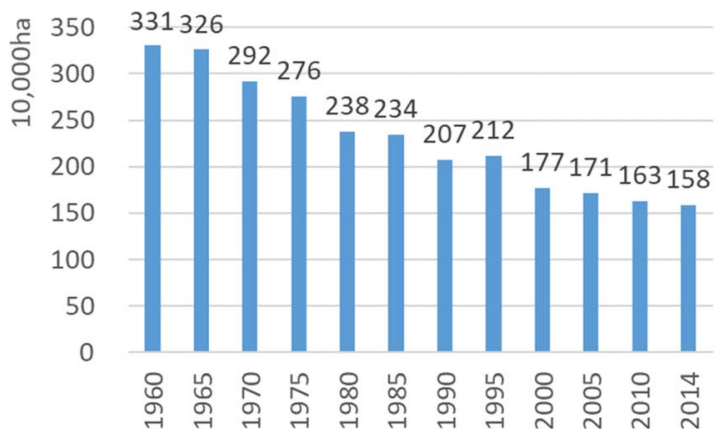

a Paddy field
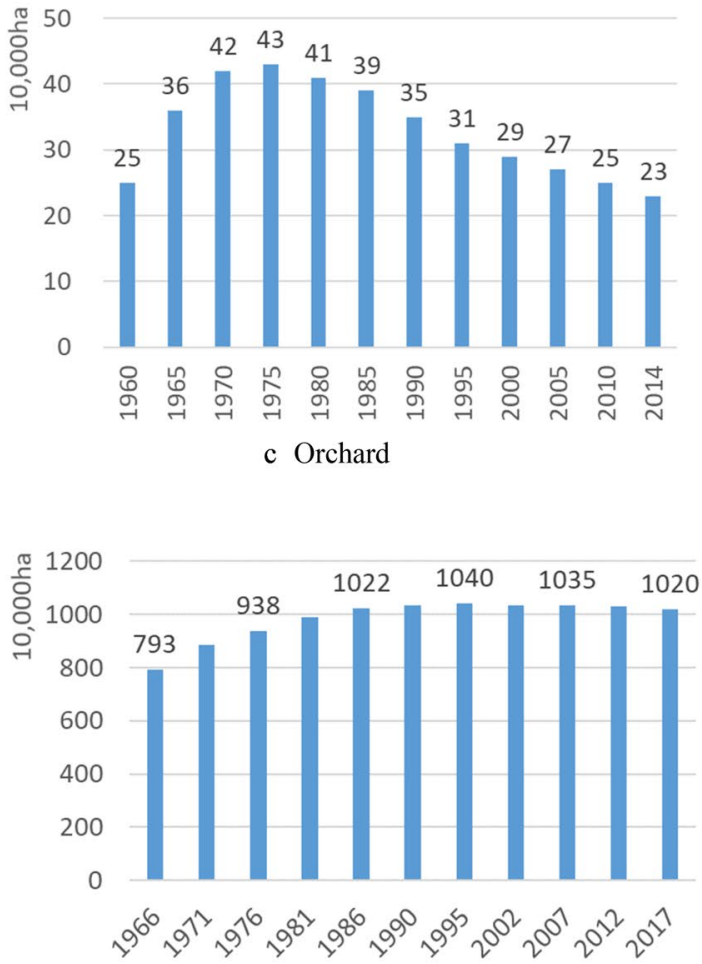

e Plantation forest

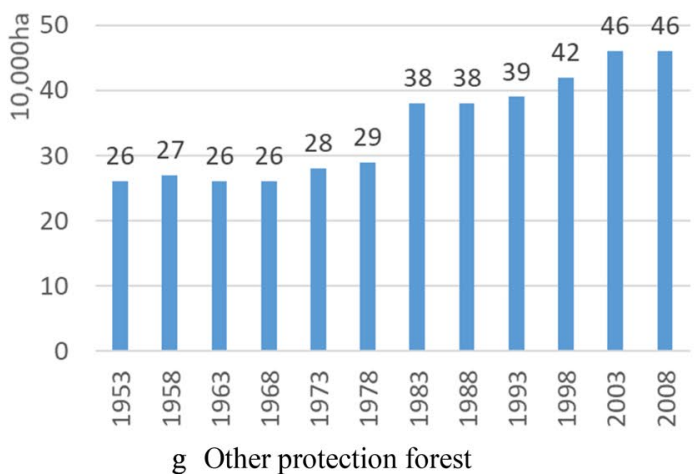

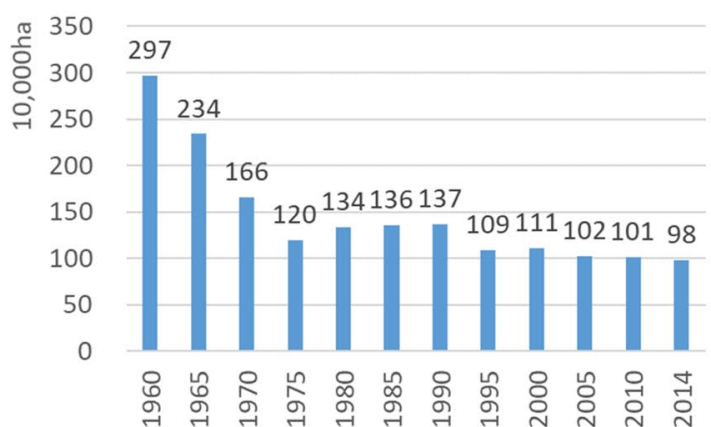

b Crop field
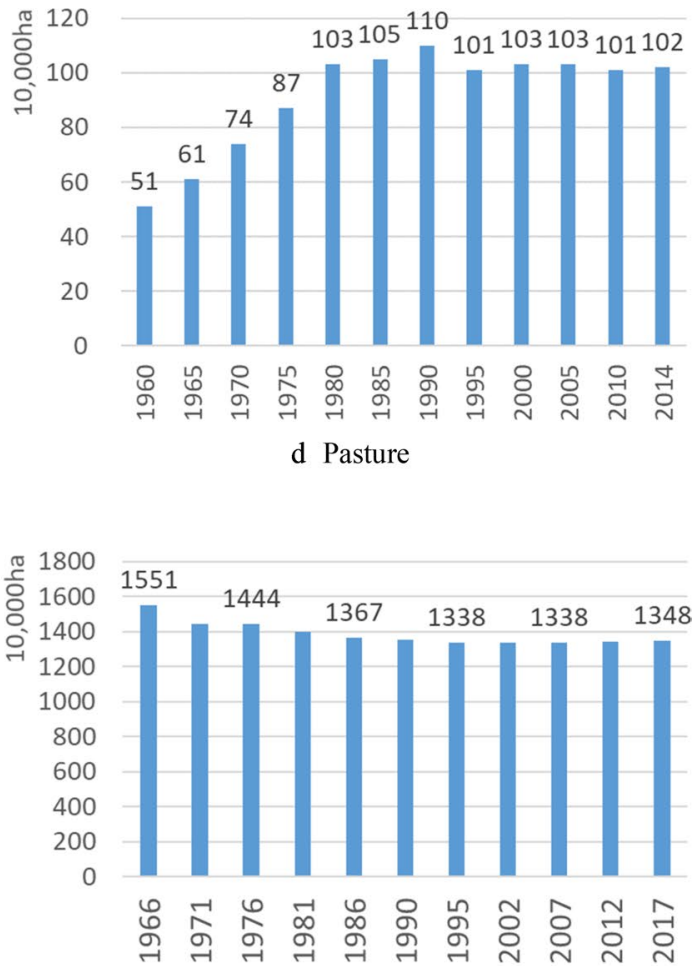

f Natural forest

Fig. 12 Trends of NCs in Japan. Data source: Fisheries Agency of Japan (2008), Forestry Agency of Japan (2010, 2017), Kokubu et al. (2017), MAFF (2018), MOE (2007, 2017), Spalding et al. (2010), Sugiawan et al. (2017), Udo et al. (2016) 

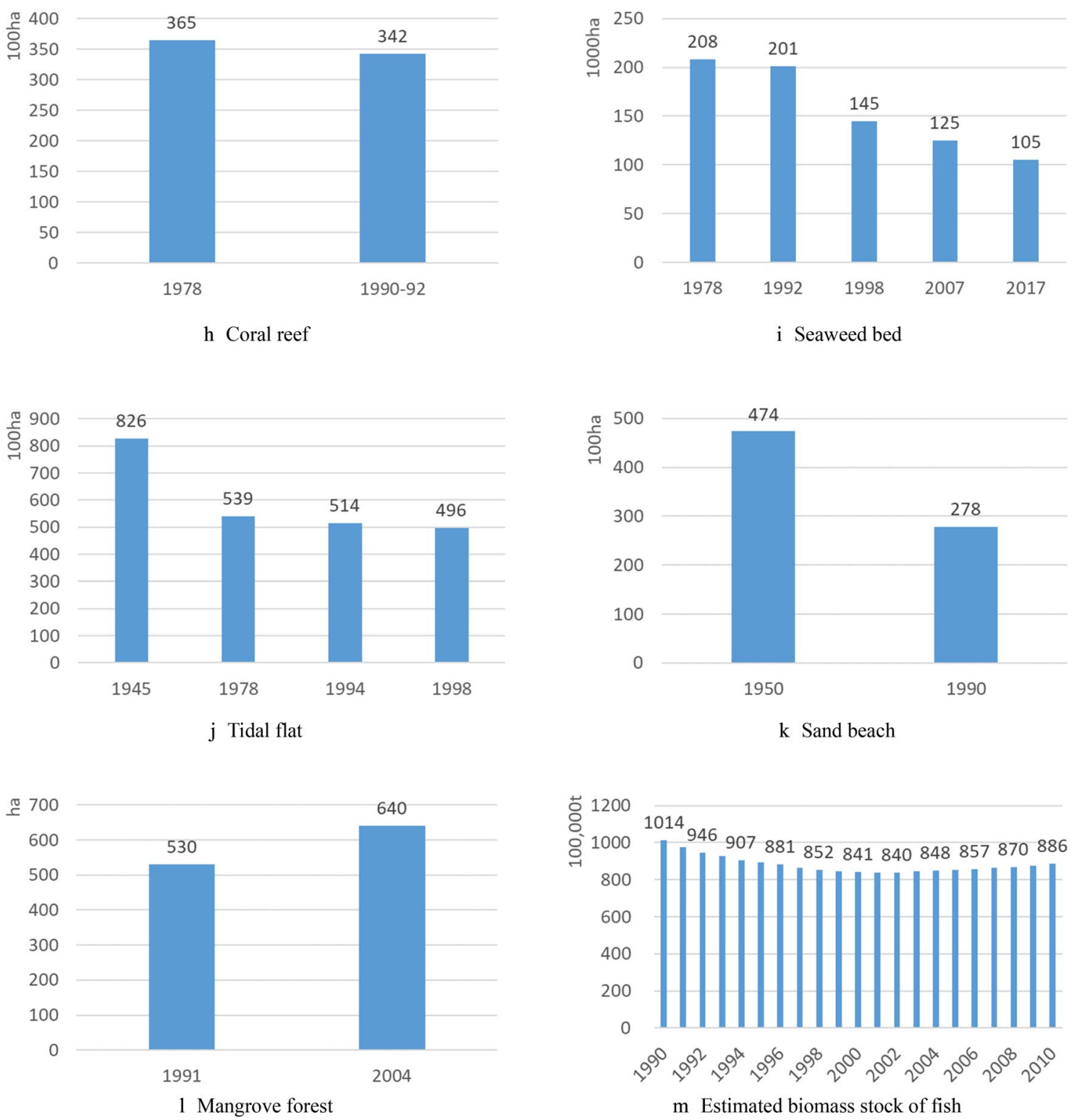

Fig. 12 (continued) 

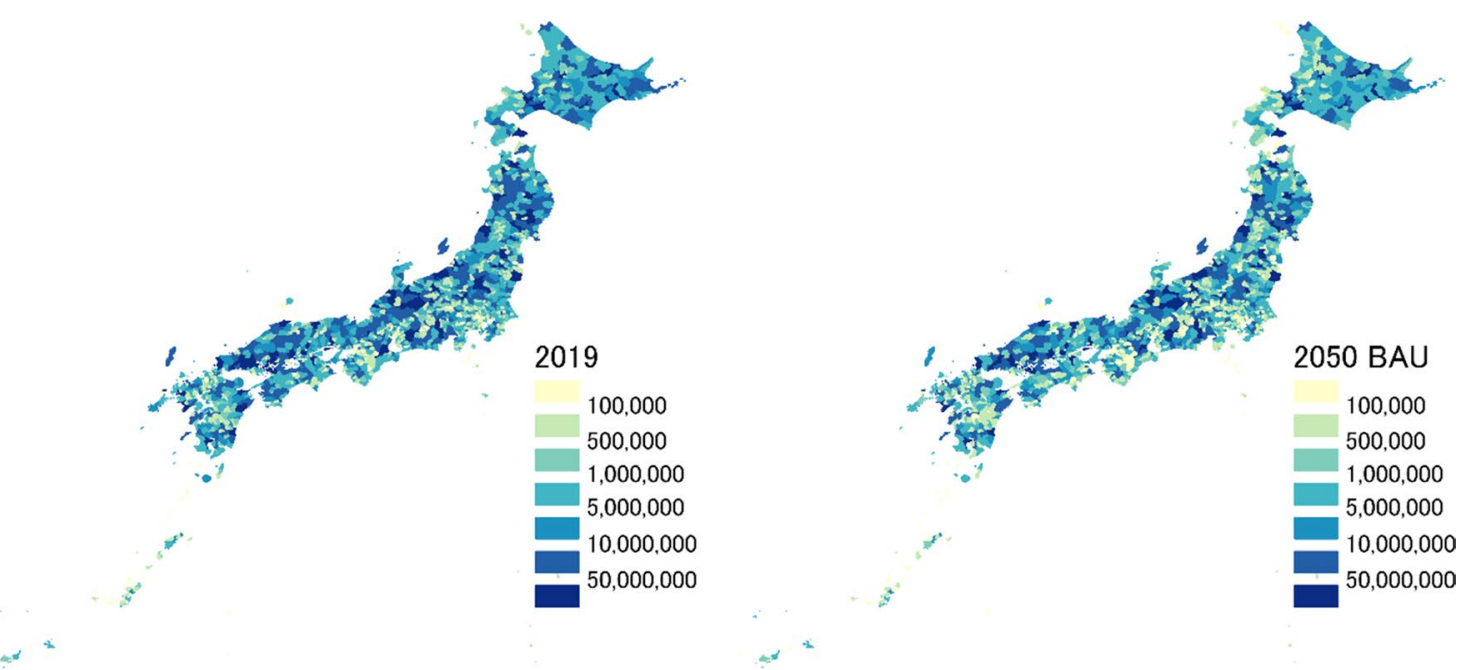

2050 NC
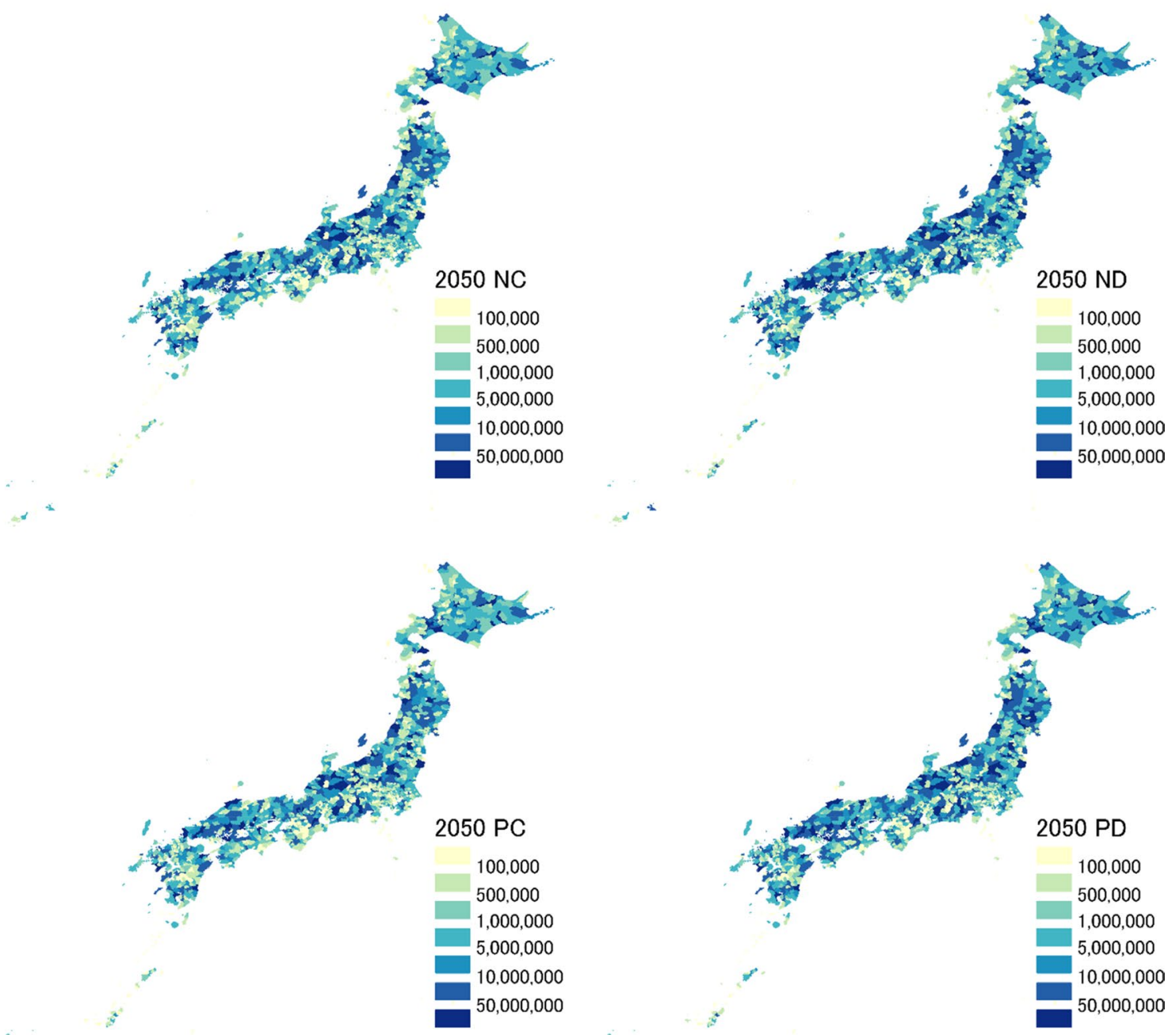

Fig. 13 Scenario prediction of terrestrial natural capital (2019 US\$) 

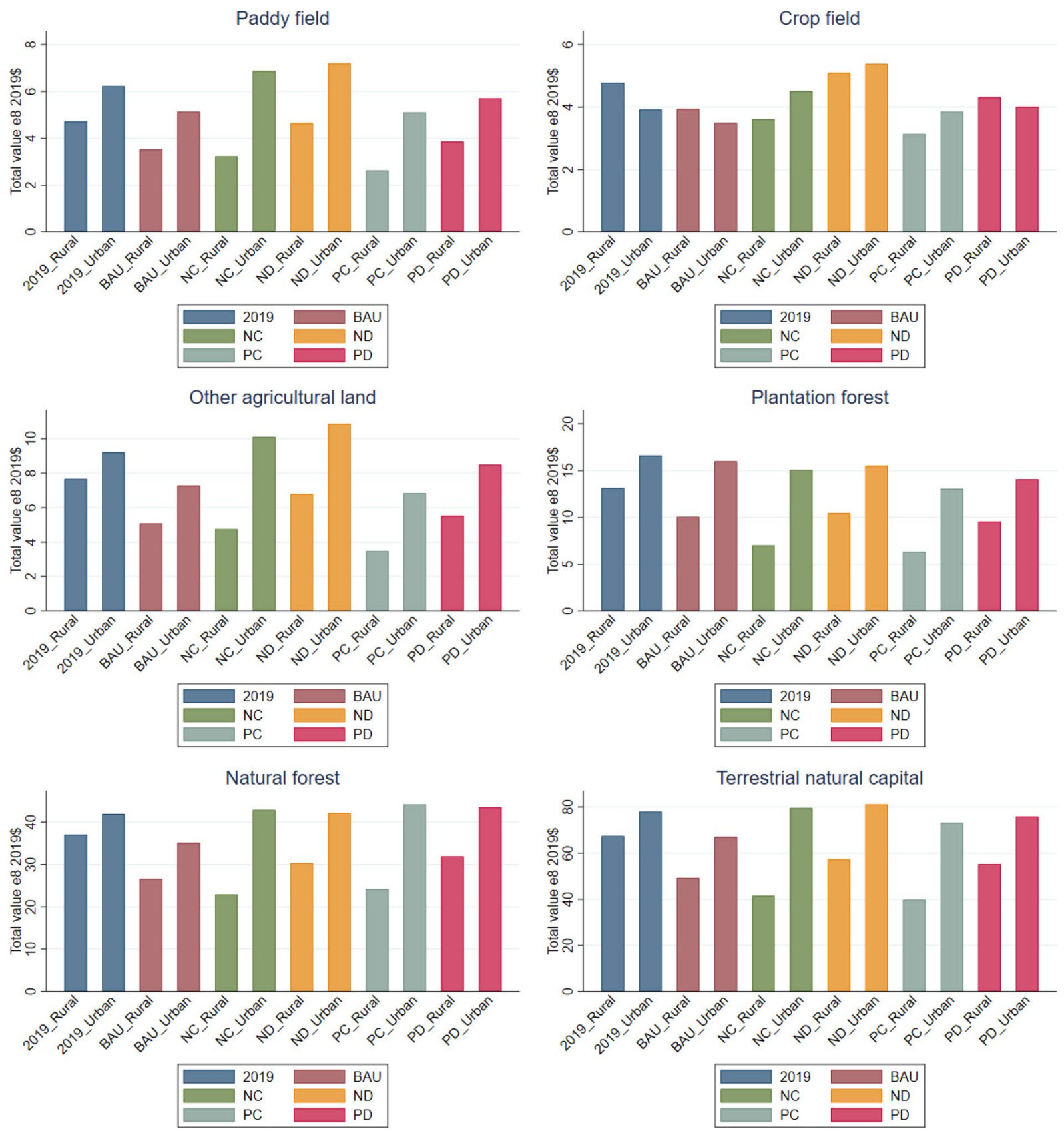

Fig. 14 Scenario prediction of each terrestrial natural capital in rural and urban area 


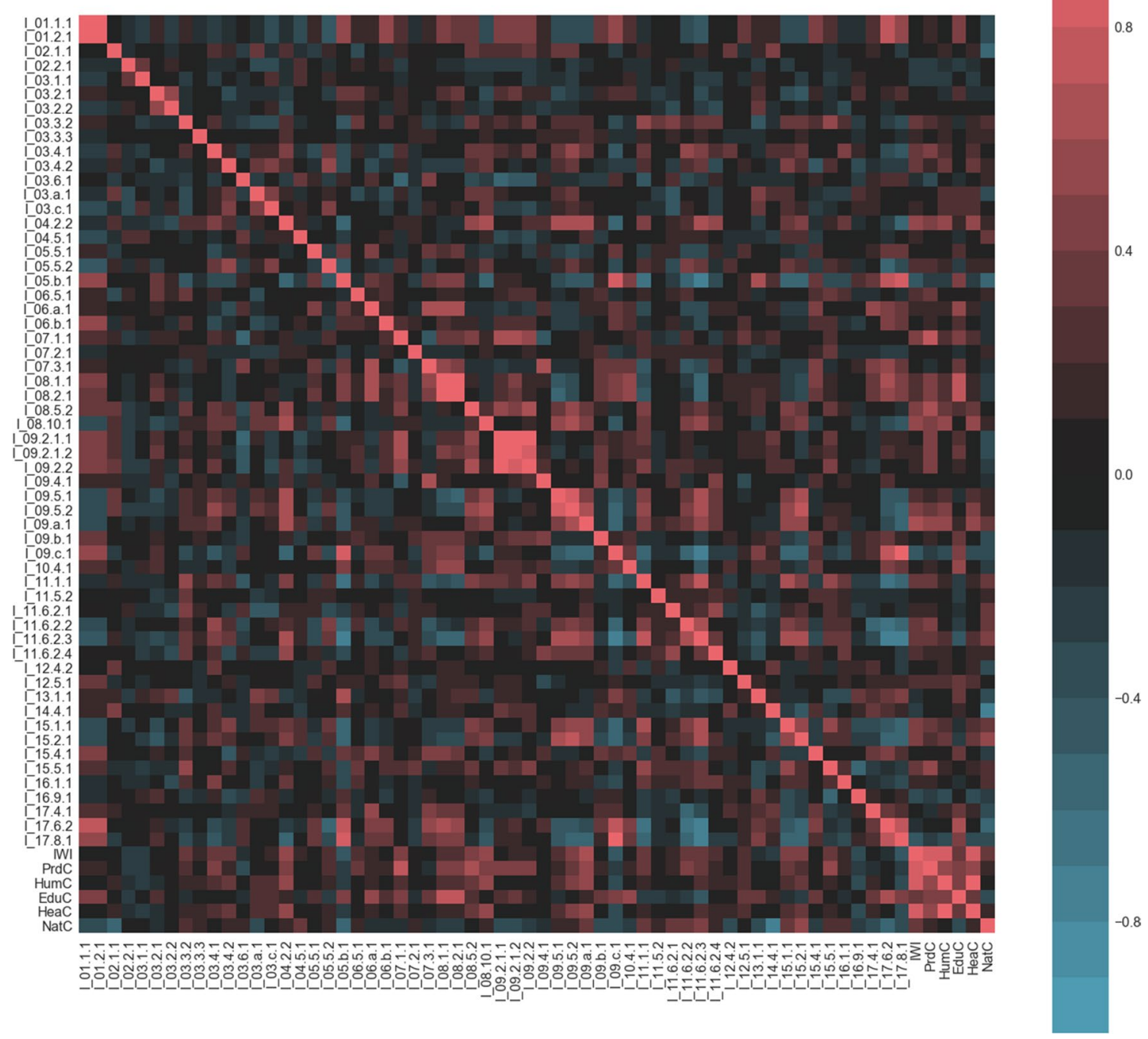

Fig. 15 Correlation heatmap among inclusive wealth index and localized SDGs indicators 


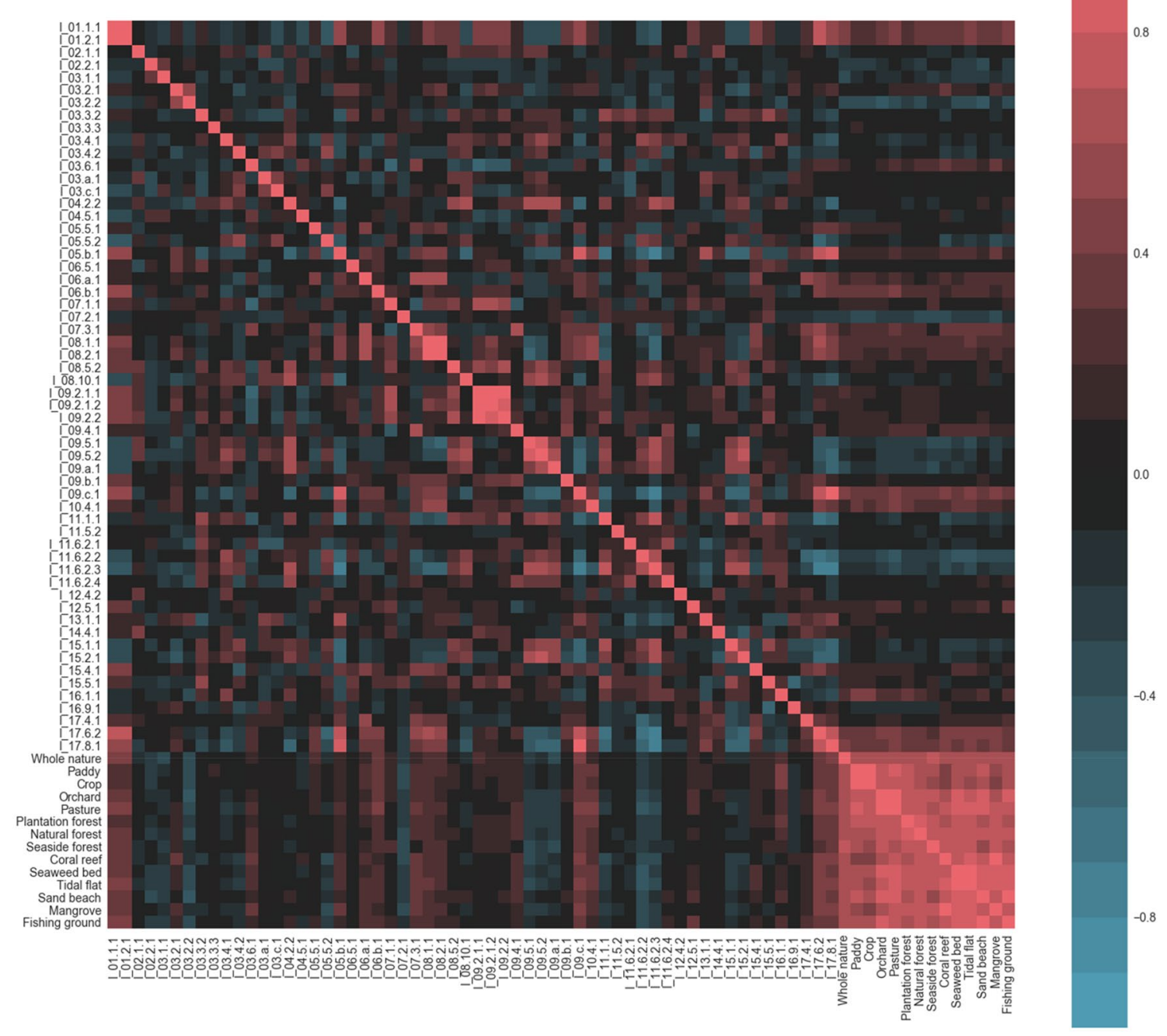

Fig. 16 Correlation heatmap among WTPs for natural capital and localized SDGs indicators 
Table $7 \mathrm{NCP}$ and decreasing scenario presented to respondents

\begin{tabular}{|c|c|c|}
\hline Natural capital & Ecosystem services & Hypothesized amount of decrease \\
\hline Paddy & $\begin{array}{l}\text { 1. Production of rice } \\
\text { 2. Regulation of groundwater quantity } \\
\text { 3. Regulation of flood } \\
\text { 4. Regulation of water quality } \\
\text { 5. Prevention of soil erosion } \\
\text { 6. Maintenance of soil nutrients } \\
\text { 7. Creation of habitat for fish, insects, frogs and wild animals } \\
\text { 8. Creation of habitat for mosquito, which transmit Japanese encepha- } \\
\text { litis } \\
\text { 9. Creation of habitat for tick, which transmit SFTS virus }\end{array}$ & 12,500 ha $(0.8 \%)$ decrease \\
\hline Crop & $\begin{array}{l}\text { 1. Production of wheat, vegetables and beans } \\
\text { 2. Regulation of groundwater quantity } \\
\text { 3. Regulation of flood } \\
\text { 4. Regulation of water quality } \\
\text { 5. Prevention of soil erosion } \\
\text { 6. Maintenance of soil nutrients } \\
\text { 7. Creation of habitat for fish, insects, frogs and wild animals } \\
\text { 8. Creation of habitat for mosquito, which transmit Japanese encepha- } \\
\text { litis } \\
\text { 9. Creation of habitat for tick, which transmit SFTS virus }\end{array}$ & 7500 ha $(0.8 \%)$ decrease \\
\hline Orchard & $\begin{array}{l}\text { 1. Production of fruits } \\
\text { 2. Regulation of groundwater quantity } \\
\text { 3. Regulation of flood } \\
\text { 4. Regulation of water quality } \\
\text { 5. Prevention of soil erosion } \\
\text { 6. Maintenance of soil nutrients } \\
\text { 7. Creation of habitat for fish, insects, frogs and wild animals } \\
\text { 8. Creation of habitat for mosquito, which transmit Japanese encepha- } \\
\text { litis } \\
\text { 9. Creation of habitat for tick, which transmit SFTS virus }\end{array}$ & 5000 ha $(2.2 \%)$ decrease \\
\hline Pasture & $\begin{array}{l}\text { 1. Production of fodder } \\
\text { 2. Regulation of groundwater quantity } \\
\text { 3. Regulation of flood } \\
\text { 4. Regulation of water quality } \\
\text { 5. Prevention of soil erosion } \\
\text { 6. Maintenance of soil nutrients } \\
\text { 7. Creation of habitat for fish, insects, frogs and wild animals } \\
\text { 8. Creation of habitat for mosquito, which transmit Japanese encepha- } \\
\text { litis } \\
\text { 9. Creation of habitat for tick, which transmit SFTS virus }\end{array}$ & 2500 ha $(0.25 \%)$ decrease \\
\hline Plantation forest & $\begin{array}{l}\text { 1. Provision of timber } \\
\text { 2. Mitigation of global warming by absorbing } \mathrm{CO} 2 \\
\text { 3. Regulation of temperature by evapotranspiration } \\
\text { 4. Regulation of groundwater quantity } \\
\text { 5. Regulation of flood } \\
\text { 6. Regulation of water quality } \\
\text { 7. Provision of soil nutrients by litterfall } \\
\text { 8. Prevention of soil erosion } \\
\text { 9. Maintenance of soil nutrients } \\
\text { 10. Creation of habitat of insects and wild animals } \\
\text { 11. Provision of recreational sites for therapeutic walk, wild plants } \\
\text { picking and picnic } \\
\text { 12. Creation of habitat for hornet } \\
\text { 13. Creation of habitat for tick, which transmit SFTS virus } \\
\text { 14. Creation of habitat for wild animals which cause crop damage }\end{array}$ & 18,000 ha $(0.2 \%)$ decrease \\
\hline
\end{tabular}


Table 7 (continued)

\begin{tabular}{|c|c|c|}
\hline Natural capital & Ecosystem services & Hypothesized amount of decrease \\
\hline Natural forest & $\begin{array}{l}\text { 1. Provision of timber } \\
\text { 2. Production of wild game meat } \\
\text { 3. Mitigation of global warming by absorbing } \mathrm{CO} 2 \\
\text { 4. Regulation of temperature by evapotranspiration } \\
\text { 5. Regulation of groundwater quantity } \\
\text { 6. Regulation of flood } \\
\text { 7. Regulation of water quality } \\
\text { 8. Provision of soil nutrients by litterfall } \\
\text { 9. Prevention of soil erosion } \\
\text { 10. Maintenance of soil nutrients } \\
\text { 11. Creation of habitat of insects and wild animals } \\
\text { 12. Provision of recreational sites for therapeutic walk, wild plants } \\
\text { picking and picnic } \\
\text { 13. Creation of habitat for hornet } \\
\text { 14. Creation of habitat for tick, which transmit SFTS virus } \\
\text { 15. Creation of habitat for wild animals which cause crop damage }\end{array}$ & 10,000 ha $(0.1 \%)$ decrease \\
\hline Seaside protection forest & $\begin{array}{l}\text { 1. Windbreak and prevention of damage by tsunami, storm surge, salt } \\
\text { pollution } \\
\text { 2. Mitigation of global warming by absorbing CO2 } \\
\text { 3. Regulation of temperature by evapotranspiration } \\
\text { 4. Regulation of groundwater quantity } \\
\text { 5. Regulation of flood } \\
\text { 6. Regulation of water quality } \\
\text { 7. Provision of soil nutrients by litterfall } \\
\text { 8. Prevention of soil erosion } \\
\text { 9. Maintenance of soil nutrients } \\
\text { 10. Creation of habitat of insects and wild animals } \\
\text { 11. Provision of recreational sites for therapeutic walk, wild plants } \\
\text { picking, picnic and so on } \\
\text { 12. Creation of habitat for hornet } \\
\text { 13. Creation of habitat for tick, which transmit SFTS virus } \\
\text { 14. Creation of habitat for wild animals which cause crop damage }\end{array}$ & 22 ha $(0.04 \%)$ decrease \\
\hline Coral reef & $\begin{array}{l}\text { 1. Increasing fish catch } \\
\text { 2. Mitigation of global warming by absorbing } \mathrm{CO} 2 \\
\text { 3. Regulation of water quality } \\
\text { 4. Creation of habitat for fish and shellfish } \\
\text { 5. Prevention of coastal erosion } \\
\text { 6. Provision of recreational places for snorkeling, diving, glass-bottom } \\
\text { boat and so on }\end{array}$ & 70 ha $(0.2 \%)$ decrease \\
\hline Seaweed bed (including rocky shore) & $\begin{array}{l}\text { 1. Increasing catch of abalone and sea urchin, kelp and seaweed, and } \\
\text { Hijiki } \\
\text { 2. Mitigation of global warming by absorbing } \mathrm{CO} 2 \\
\text { 3. Regulation of water quality } \\
\text { 4. Prevention of coastal erosion } \\
\text { 5. Creation of habitat of fish, shellfish and wild animals } \\
\text { 6. Provision of recreational sites for fishing and gathering shellfish } \\
\text { and crabs }\end{array}$ & 2000 ha $(1.9 \%)$ decrease \\
\hline Tidal flat (including Eelgrass bed) & $\begin{array}{l}\text { 1. Increasing catch of clams } \\
\text { 2. Mitigation of global warming by absorbing } \mathrm{CO} 2 \\
\text { 3. Regulation of water quality } \\
\text { 4. Creation of habitat of fish, shellfish and wild animals } \\
\text { 5. Provision of recreational sites for clamming, birdwatching, and so } \\
\text { on }\end{array}$ & 99 ha $(0.2 \%)$ decrease \\
\hline Sand beach & $\begin{array}{l}\text { 1. Provision of sand } \\
\text { 2. Regulation of water quality } \\
\text { 3. Regulation of groundwater quantity } \\
\text { 4. Provision of recreational sites for swimming and playing on the } \\
\text { beach } \\
\text { 5. Generation of wind-blown sand and salt damage }\end{array}$ & 56 ha $(0.2 \%)$ decrease \\
\hline
\end{tabular}


Table 7 (continued)

\begin{tabular}{lll}
\hline Natural capital & Ecosystem services & Hypothesized amount of decrease \\
\hline Mangrove forest & 1. Provision of timber & 1.5 ha $(0.2 \%)$ decrease \\
2. Mitigation of global warming by absorbing CO2 & 3. Regulation of temperature by evapotranspiration \\
4. Regulation of groundwater quantity & 5. Regulation of flood \\
6. Regulation of water quality & 7. Provision of soil nutrients by litterfall \\
8. Prevention of soil erosion & 9. Maintenance of soil nutrients \\
& 10. Creation of habitat of insects and wild animals \\
& 11. Prevention of coastal erosion \\
12. Prevention of damage by strong wind and storm surge & 13. Provision of recreational sites for canoe and so on \\
14. Creation of habitat for mosquito & 15. Easy to be polluted by solid waste \\
1. Provision of diversified marine products & 2. Regulation of water quality \\
Fishing ground & 4. Provision of recreational places for fishing and so on \\
&
\end{tabular}

Table 8 Definition of localized SDGs indicators (Matsui et al. 2019)

\section{1 . No poverty}

01.1 .1

01.2 .1

02. Zero hunger

02.1 .1

02.2 .1

03. Good health and well-being

03.1 .1

03.2 .1

03.2 .2

03.3 .2

03.3 .3

03.4 .1

03.4 .2

03.6.1

03.a.1

03.c. 1

04. Quality education

04.5 .1

05 . Gender equality

05.5 .1

05.5 .2

05.b. 1

06. Clean water and sanitation

06.5 .1

06.a. 1

06.b.1
Relative poverty rate (number of households with annual income less than 1.22 million yen/ number of all households)

Relative poverty rate (number of households with annual income less than 1.22 million yen/ number of all households)

Total patient proportion in malnutrition or vitamin deficiency

Percentage of people with developmental disabilities

Maternal mortality rate

Under-five mortality rate

Neonatal mortality

TB incident rate

Malaria mortality rate

Mortality of cardiovascular disease, cancer, diabetes

Suicide rate

Mortality from road traffic accidents

Smoking rate

Number of doctors per population

Nursery utilization rate

Parity index

Percentage of women in prefectural assembly

Percentage of female executives

Percentage of people who own mobile devices

Number of waterworks per population

Sewerage cost per population

Sewer business start-up rate 
Table 8 (continued)

07. Affordable and clean energy

07.1 .1

07.2 .1

07.3.1

08. Decent work and economic growth

08.2 .1

08.5 .2

08.10 .1

09. Industry, innovation and infrastructure

09.2.1.2

09.2 .2

09.4 .1

09.5 .1

09.5 .2

09.a.1

09.b.1

09.c. 1

10. Reduced inequalities

10.4.1

11. Sustainable cities and communities

11.1.1

11.5.2

11.6.2.1

11.6.2.2

11.6.2.3

11.6.2.4

12. Responsible consumption and production

12.4 .2

12.5 .1

13. Climate action

13.1.1

14. Life below water

14.4.1

15. Life on land

15.1 .1

15.2 .1

15.4.1

15.5.1

16. Peace, justice and strong institutions

16.1.1

16.9.1

17. Partnerships for the goals

17.4.1

17.6.2

17.8 .1
Electricity energy consumption per population

New energy power generation ratio

Gross regional product per energy consumption

Gross regional product per capita

Gross regional product per workers

Unemployment rate

Number of banks per population

Gross value added of manufacturing industry per gross regional product

Gross value added of manufacturing industry per population

Percentage of manufacturing workers

$\mathrm{CO} 2$ emissions from manufacturing industry per gross value added

Research and development costs per gross regional product

Number of researchers per million

Ratio of civil engineering expenses to annual expenditure

Gross value added of the electrical machinery/equipment manufacturing industry per total gross value added at office with 4 or more employees

Internet usage rate

Labor productivity

Percentage of homeless people

Disaster recovery costs as a percentage of annual expenditure

Annual average value of PM2.5

Number of days when the photochemical oxidant (Ox) concentration during the day was 0.12 ppm or more

Annual average value of $\mathrm{NO}_{x}$

Annual average value of $\mathrm{SO}_{2}$

Hazardous waste rate

Recycling rate

Percentage of victims of natural causes such as disasters

Rate of change in catch and aquaculture yield

Percentage of forested area

Number of forestry test instructors per population

Percentage of biological conservation area

Number of endangered species per area

Number of murder recognition cases per population

Percentage of population under 5

Real debt service ratio

Internet broadband subscription household ratio

Internet usage rate 


\section{Compliance with ethical standards}

Conflict of interest On behalf of all authors, the corresponding author states that there is no conflict of interest.

Open Access This article is licensed under a Creative Commons Attribution 4.0 International License, which permits use, sharing, adaptation, distribution and reproduction in any medium or format, as long as you give appropriate credit to the original author(s) and the source, provide a link to the Creative Commons licence, and indicate if changes were made. The images or other third party material in this article are included in the article's Creative Commons licence, unless indicated otherwise in a credit line to the material. If material is not included in the article's Creative Commons licence and your intended use is not permitted by statutory regulation or exceeds the permitted use, you will need to obtain permission directly from the copyright holder. To view a copy of this licence, visit http://creativecommons.org/licenses/by/4.0/.

\section{References}

Bagozzi BE, Hill DW, Moore WH, Mukherjee B (2012) Modeling two types of zeros in ordinal data : the zero-inflated ordered probit $(\mathrm{ZiOP})$ model in conflict researchs

Blaine TW, Lichtkoppler FR, Jones KR, Zondag RH (2005) An assessment of household willingness to pay for curbside recycling: a comparison of payment card and referendum approaches. J Environ Manag 76(1):15-22. https://doi.org/10. 1016/j.jenvman.2005.01.004

Brockerhoff EG, Jactel H, Parrotta JA, Quine CP, Sayer J (2008) Plantation forests and biodiversity: oxymoron or opportunity? Biodivers Conserv 17(5):925-951. https://doi.org/10.1007/ s10531-008-9380-x

Collados C, Duane TP (1999) Natural capital and quality of life: a model for evaluating the sustainability of alternative regional development paths. Ecol Econ 30(3):441-460. https://doi.org/ 10.1016/S0921-8009(99)00020-8

Costanza R, Arge R, Groot RD, Farber S, Hannon B, Limburg K, Naeem S, Neill RVO, Paruelo J, Raskin RG, Sutton P, Costanza $\mathrm{R}$, Groot D (1997) Massey research online the value of the world's ecosystem services and natural capital. Nature 387(6630):253-260

Costanza R, de Groot R, Braat L, Kubiszewski I, Fioramonti L, Sutton P, Farber S, Grasso M (2017) Twenty years of ecosystem services: how far have we come and how far do we still need to go? Ecosyst Serv 28:1-16. https://doi.org/10.1016/j.ecoser.2017.09.008

Costanza R, de Groot R, Sutton P, van der Ploeg S, Anderson SJ, Kubiszewski I, Farber S, Turner RK (2014) Changes in the global value of ecosystem services. Glob Environ Change 26(1):152158. https://doi.org/10.1016/j.gloenvcha.2014.04.002

de Groot R, Brander L, van der Ploeg S, Costanza R, Bernard F, Braat L, Christie M, Crossman N, Ghermandi A, Hein L, Hussain S, Kumar P, McVittie A, Portela R, Rodriguez LC, ten Brink P, van Beukering P (2012) Global estimates of the value of ecosystems and their services in monetary units. Ecosyst Serv 1(1):50-61. https://doi.org/10.1016/j.ecoser.2012.07.005

Díaz S, Pascual U, Stenseke M, Martín-López B, Watson RT, Molnár Z, Hill R, Chan KMA, Baste IA, Brauman KA, Polasky S, Church A, Lonsdale M, Larigauderie A, Leadley PW, van Oudenhoven APE, van der Plaat F, Schröter M, Lavorel S, Aumeeruddy-Thomas Y, Bukvareva E, Davies K, Demissew S, Erpul G, Failler P, Guerra CA, Hewitt CL, Keune H, Lindley S, Shirayama Y (2018) Assessing nature's contributions to people. Science 359(6373):270-272. https://doi.org/10.1126/science.aap8826
Egusa T, Kumagai T, Shiraishi N (2020) Carbon stock in Japanese forests has been greatly underestimated. Sci Rep 10(1):1-9. https://doi.org/10.1038/s41598-020-64851-2

Ekins P, Simon S, Deutsch L, Folke C, De Groot R (2003) A framework for the practical application of the concepts of critical natural capital and strong sustainability. Ecol Econ 44(2-3):165185. https://doi.org/10.1016/S0921-8009(02)00272-0

Fisheries Agency of Japan (2008) Current status and problems of seaweed beds and tidal flats. Retrieved from https://www.jfa. maff.go.jp/j/study/kikaku/moba_higata/pdf/1siryou.pdf

Forestry Agency of Japan (2010) Annual report on trends in forest and forestry in Japan fiscal year 2009. Retrieved from https:// www.rinya.maff.go.jp/j/kikaku/hakusyo/21 hakusho/190411. html

Forestry Agency of Japan (2017) Current status of forest resources. Retrieved from https://www.rinya.maff.go.jp/j/keikaku/genky ou/h29/index.html

Fujii H, Managi S (2016) An evaluation of inclusive capital stock for urban planning. Ecosyst Health Sustain 2(10):1-11. https://doi. org/10.1002/ehs2.1243

Fujii H, Sato M, Managi S (2017) Decomposition analysis of forest ecosystem services values. Sustainability (Switzerland). https:// doi.org/10.3390/su9050687

Fujioka M, Lane SJ (1997) The impact of changing irrigation practices in rice fields on frog populations of the Kanto Plain, central Japan. Ecol Res 12(1):101-108. https://doi.org/10.1007/BF02523615

Harris MN, Zhao X (2007) A zero-inflated ordered probit model, with an application to modelling tobacco consumption. J Econom 141(2):1073-1099. https://doi.org/10.1016/j.jeconom.2007.01. 002

Hilgarter K, Granig P (2020) Public perception of autonomous vehicles: a qualitative study based on interviews after riding an autonomous shuttle. Transp Res Part F Traffic Psychol Behav 72:226-243. https://doi.org/10.1016/j.trf.2020.05.012

Hori K, Saito O, Hashimoto S, Matsui T, Akter R, Takeuchi K (2020a) Projecting population distribution under depopulation conditions in Japan: scenario analysis for future socioecological systems. Sustain Sci. https://doi.org/10.1007/ s11625-020-00835-5

Hori K, Shirahama S, Hashimoto S, Saito O, Matsui T, Haga C (2020) Exploring the spatial scale for construction of "regional circulating and ecological sphere" by ecological footprint indicator

Ikeda S, Managi S (2019) Future inclusive wealth and human wellbeing in regional Japan: projections of sustainability indices based on shared socioeconomic pathways. Sustain Sci 14(1):147-158. https://doi.org/10.1007/s11625-018-0589-7

Iwamatsu S, Suzuki A, Sato M (2007) Nereidid polychaetes as the major diet of migratory shorebirds on the estuarine tidal flats at Fujimae-Higata in Japan. Zoolog Sci 24(7):676-685. https:// doi.org/10.2108/zsj.24.676

Kagohashi K (2017) Critical natural capital and sustainability. Rev Environ Econ Pol Stud 10(2):18-31. https://doi.org/10.14927/ reeps.10.2_18

Katano O, Hosoya K, Iguchi K, Yamaguchi M, Aonuma Y, Kitano S (2003) Species diversity and abundance of freshwater fishes in irrigation ditches around rice fields. Environ Biol Fishes 66(2):107-121. https://doi.org/10.1023/A:1023678401886

Kato H, Yamagishi T, Shimada T, Matsui T, Shimojima M, Saijo M, Oishi K, Abe M, Wada M, Umekita K, Kamekou M, Tanioka D, Sanada I, Kuwai T, Tanaka Y, Shigetou K, Homma Y, Yamamoto C, Yamauchi M, Hayashi S, Watanabe S, Kitao A, Takatsu H, Nakanishi Y, Koguro K, Watanabe M, Uehara N, Kaneko M, Yamanaka A, Murakami Y, Konishi T, Sakamoto A, Harada M, Yamamoto K, Hayashi T, Kondo N, Suemori K, Ogawa T, Nakazawa R, Yamamoto Y, Miyahara M, Senba T, Maruhashi T, Fukushi S, Tani H, Yoshikawa T, Morikawa S (2016) Epidemiological 
and clinical features of severe fever with thrombocytopenia syndrome in Japan, 2013-2014. PLoS ONE 11(10):2013-2014. https://doi.org/10.1371/journal.pone.0165207

Kleijn D, Báldi A (2005) Effects of set-aside land on farmland biodiversity: comments on Van Buskirk and Willi. Conserv Biol 19(3):963-966. https://doi.org/10.1111/j.1523-1739.2005.00603.x

Kokubu H, Ishii Y, Miyazaki H, Yabe T (2017) Estimation of carbon storage in tidal flat and Zostera Marina bed in Ise Bay toward a blue carbon evaluation. J Jpn Soc Civ Eng Ser B2 Coast Eng 73(1):2-7. https://doi.org/10.2208/kaigan.73.I_1261

Kriström B (1990) A non-parametric approach to the estimation of welfare measures in discrete response valuation studies. Land Econ 66(2):135-139. https://doi.org/10.2307/3146363

Lee JS, Mogasale V, Lim JK, Carabali M, Sirivichayakul C, Anh DD, Lee KS, Thiem VD, Limkittikul K, Tho LH, Velez ID, Osorio JE, Chanthavanich P, da Silva LJ, Maskery BA (2015) A multicountry study of the household willingness-to-pay for dengue vaccines: household surveys in Vietnam, Thailand, and Colombia. PLoS Negl Trop Dis 9(6):1-15. https://doi.org/10.1371/journal. pntd.0003810

MacDonald D, Crabtree JR, Wiesinger G, Dax T, Stamou N, Fleury P, Gutierrez Lazpita J, Gibon A (2000) Agricultural abandonment in mountain areas of Europe: environmental consequences and policy response. J Environ Manag 59(1):47-69. https://doi.org/ 10.1006/jema.1999.0335

MacDonald DV, Hanley N, Moffatt I (1999) Applying the concept of natural capital criticality to regional resource management. Ecol Econ 29(1):73-87. https://doi.org/10.1016/S0921-8009(98) 00051-2

Managi S, Kumar P (2018) Inclusive wealth report 2018. Routledge. https://doi.org/10.4324/9781351002080

Matsui T, Kawawake A, Iwami A, Masuhara N, Takashi M (2019) Structure analysis of SDGs network based on NEXUS approach. J Jpn Soc Civ Eng Ser G Environ Res 75(6):39-47. https://doi. org/10.2208/jscejer.75.6_II_39

Matsushita T, Kitsuki A, Managi S (2019) A study on residential choice of elderly people in Japan. J Jpn Soc Civ Eng Ser D3 Infrastruct Plan Manag 75(5):347-352

Miller JR (2005) Biodiversity conservation and the extinction of experience. Trends Ecol Evol 20(8):430-434. https://doi.org/10.1016/j. tree.2005.05.013

Ministry of Agriculture, Forestry and Fisheries (2017) Current situation of forest resources. Retrieved August 8, 2020, from https:// www.rinya.maff.go.jp/j/keikaku/genkyou/h29/index.html

Ministry of Agriculture, Forestry and Fisheries (2018) Statistics of cultivated area and crop acreage. Retrieved from https://www. maff.go.jp/j/tokei/kouhyou/sakumotu/menseki/

Ministry of Agriculture, Forestry and Fisheries (2020) Current situation and countermeasures of devastated farmland. Retrieved from https://www.maff.go.jp/j/nousin/tikei/houkiti/Genzyo/PDF/Genzyo_0204.pdf

Ministry of Land, Infrastructure, Transport and Tourism (2014) National Land Numerical Information. Retrieved from http:// nlftp.mlit.go.jp/ksj/

Ministry of Land, Infrastructure, Transport and Tourism (2016) Biodiversity index among urban cities. Retrieved August 18, 2020, from https://www.mlit.go.jp/common/001152339.pdf

Ministry of the Environment (1994) The report of the marine biotic environment survey in the 4th National Survey on the Natural Environment. Retrieved from https://www.biodic.go.jp/reports/412/r00a.html

Ministry of the Environment (2005) Natural environmental information GIS. Retrieved from http://gis.biodic.go.jp/webgis/

Ministry of the Environment (2007) Round-table conference on conservation and use of sea areas related to national and quasi-national parks. Retrieved from https://www.env.go.jp/nature/koen_umi/
Ministry of the Environment (2017) Annual report on environmental statistics 2017. Retrieved from http://www.env.go.jp/en/statistics/ e2017.html

Mukai Y, Baba N, Ishii M (2005) The water system of traditional rice paddies as an important habitat of the giant water bug, Lethocerus deyrollei (Heteroptera: Belostomatidae). J Insect Conserv 9(2):121-129. https://doi.org/10.1007/s10841-005-3488-z

NASA Goddard Space Flight Center, Ocean Ecology Laboratory, Ocean Biology Processing Group (2018) Moderate-resolution Imaging Spectroradiometer (MODIS) Aqua Chlorophyll Data. https://doi.org/10.5067/AQUA/MODIS/L3M/CHL/2018

Natuhara Y (2013) Ecosystem services by paddy fields as substitutes of natural wetlands in Japan. Ecol Eng 56:97-106. https://doi. org/10.1016/j.ecoleng.2012.04.026

Navarro LM, Pereira HM (2012) Rewilding abandoned landscapes in Europe. Ecosystems 15(6):900-912. https://doi.org/10.1007/ s10021-012-9558-7

Noel JF, O'Connor M (1998) Strong sustainability and critical natural capital. In: O'Connor M (ed) Valuation for sustainable development: methods and policy indicators. Edward Elgar, Cheltenham/Northampton. pp. 75-97, https://doi.org/https:// doi.org/10.4337/9781782544708.00012

Osawa T, Kohyama K, Mitsuhashi H (2013) Areas of increasing agricultural abandonment overlap the distribution of previously common, currently threatened plant species. PLoS ONE 8(11):1-9. https://doi.org/10.1371/journal.pone.0079978

Pucher J, Renne JL (2005) Rural mobility and mode choice: evidence from the 2001 National Household Travel Survey. Transportation 32(2):165-186. https://doi.org/10.1007/s11116-004-5508-3

Rees WE (1992) Ecological footprints and appropriated carrying capacity: what urban economics leaves out. Environ Urban 4(2):121-130. https://doi.org/10.1177/095624789200400212

Riahi K, van Vuuren DP, Kriegler E, Edmonds J, O’Neill BC, Fujimori S, Bauer N, Calvin K, Dellink R, Fricko O, Lutz W, Popp A, Cuaresma JC, Kc S, Leimbach M, Jiang L, Kram T, Rao S, Emmerling J, Ebi K, Hasegawa T, Havlik P, Humpenöder F, Da Silva LA, Smith S, Stehfest E, Bosetti V, Eom J, Gernaat D, Masui T, Rogelj J, Strefler J, Drouet L, Krey V, Luderer G, Harmsen M, Takahashi K, Baumstark L, Doelman JC, Kainuma M, Klimont Z, Marangoni G, Lotze-Campen H, Obersteiner M, Tabeau A, Tavoni M (2017) The shared socioeconomic pathways and their energy, land use, and greenhouse gas emissions implications: an overview. Glob Environ Change 42:153-168. https://doi.org/10. 1016/j.gloenvcha.2016.05.009

Saito O, Kamiyama C, Hashimoto S, Matsui T, Shoyama K, Kabaya K, Uetake T, Taki H, Ishikawa Y, Matsushita K, Yamane F, Hori J, Ariga T, Takeuchi K (2019) Co-design of national-scale future scenarios in Japan to predict and assess natural capital and ecosystem services. Sustain Sci 14(1):5-21. https://doi.org/10.1007/ s11625-018-0587-9

Shoyama K, Matsui T, Hashimoto S, Kabaya K, Oono A, Saito O (2019) Development of land-use scenarios using vegetation inventories in Japan. Sustain Sci 14(1):39-52. https://doi.org/10.1007/ s11625-018-0617-7

Soga M, Gaston KJ, Yamaura Y, Kurisu K, Hanaki K (2016) Both direct and vicarious experiences of nature affect children's willingness to conserve biodiversity. Int J Environ Res Public Health. https://doi.org/10.3390/ijerph13060529

Spalding M, Kainuma M, Collins L (2010) World Atlas of Mangroves. Routledge, London

Sugiawan Y, Islam M, Managi S (2017) Global marine fisheries with economic growth. Econ Anal Policy 55:158-168. https://doi.org/ 10.1016/j.eap.2017.08.004 
Tsunoda H, Enari H (2020) A strategy for wildlife management in depopulating rural areas of Japan. Conserv Biol 34(4):819-828. https://doi.org/10.1111/cobi.13470

Tsunoda T, Mori K (2000) No distributional association between the tick Haemaphysalis longicornis (Acari: Ixodidae) and plant surface area. Ecol Res 15(3):357-359. https://doi.org/10.1046/j. 1440-1703.2000.00353.x

Turnbull BW (1976) The empirical distribution function with arbitrarily grouped, censored and truncated data. J Roy Stat Soc B37(3):290-295

Udo K, Takeda Y, Yokoo Y (2016) Relationship between potential sediment supply from river to sea and beach erosion in Japan. J Jpn Soc Civ Eng Ser B2 Coast Eng 72(2):799-804. https://doi. org/10.2208/kaigan.72.I_799

Umenai T, Krzysko R, Bektimirov TA, Assaad FA (1985) Japanese encephalitis: current worldwide status. Bull World Health Organ 63(4):625-631
United Nations (2015) Transforming our world: the 2030 agenda for sustainable development. United Nations, New York

United Nations Department of Economic and Social Affairs Statistics Devision (2017) SDG indicators. Retrieved August 20, 2020, from https://unstats.un.org/sdgs/indicators/indicators-list/

UNU Ihdp and UNEP (2014) Inclusive wealth report 2014-measuring progress toward sustainability. Cambridge University Press, Cambridge. https://doi.org/10.1108/ijshe.2012.24913daa.006

Vaughan WJ, Rodriguez DJ (2001) Obtaining welfare bounds in discrete-response valuation studies: Comment. Land Econ 77(3):457-465. https://doi.org/10.2307/3147136

Zhang W, Goodale E, Chen J (2014) How contact with nature affects children's biophilia, biophobia and conservation attitude in China. Biol Cons 177:109-116. https://doi.org/10.1016/j.biocon.2014. 06.011

Publisher's Note Springer Nature remains neutral with regard to jurisdictional claims in published maps and institutional affiliations. 